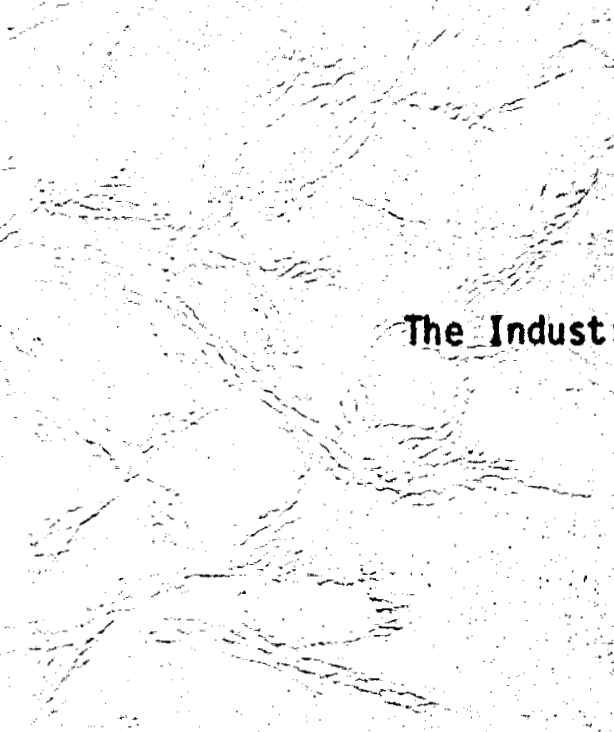

$$
\begin{aligned}
& \text { edited by } \\
& \text { J. Stringfellow }
\end{aligned}
$$

Final Report

October 1982

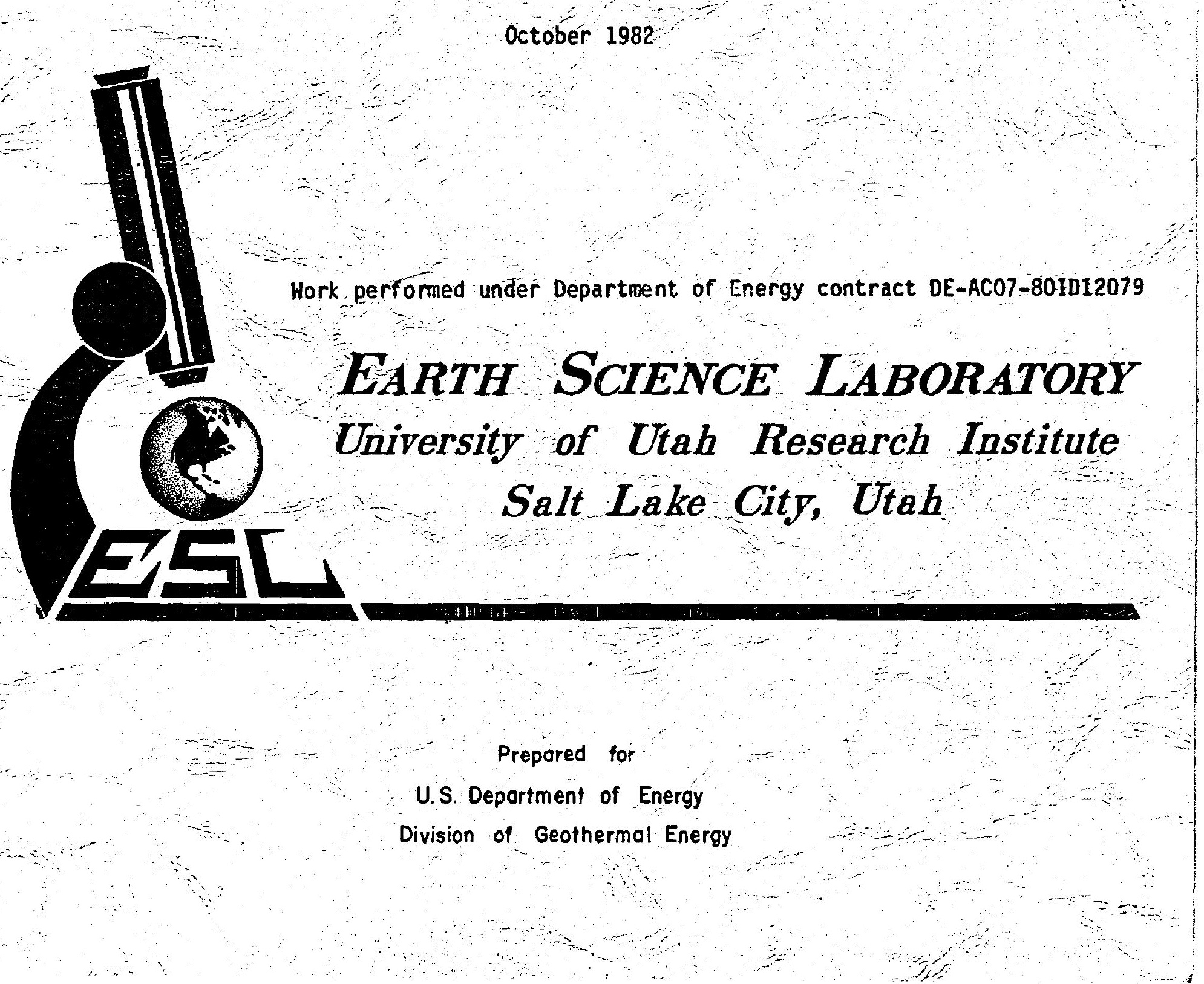




\section{DISCLAIMER}

This report was prepared as an account of work sponsored by an agency of the United States Government. Neither the United States Government nor any agency Thereof, nor any of their employees, makes any warranty, express or implied, or assumes any legal liability or responsibility for the accuracy, completeness, or usefulness of any information, apparatus, product, or process disclosed, or represents that its use would not infringe privately owned rights. Reference herein to any specific commercial product, process, or service by trade name, trademark, manufacturer, or otherwise does not necessarily constitute or imply its endorsement, recommendation, or favoring by the United States Government or any agency thereof. The views and opinions of authors expressed herein do not necessarily state or reflect those of the United States Government or any agency thereof. 


\section{DISCLAIMER}

Portions of this document may be illegible in electronic image products. Images are produced from the best available original document. 


\section{J. Stringfellow editor}

October 1982

Prepared for the Department of Energy, Division of Geotherma 1 Energy Earth Science Laboratory, University of Utah Research Institute 420 Chipeta Way, Suite 120

Salt Lake City, Utah 
ABSTRACT..................................................

PART I The Industry Coupled Case Study Program....................2

PART II Bibliography of Reports

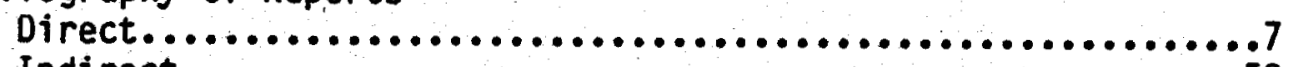

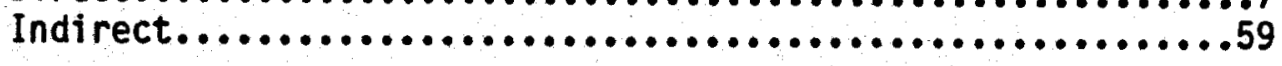

PART III Listing of Open-file Material ......................... 84

PART IV Catalog of Geothermal Sample Library......................96 


\section{NOTICE}

This report was prepared to document work sponsored by the United States Government. Neither the United States nor its agent, the United States Department of Energy, nor any Federal employees, nor any of their contractors, subcontractors or their employees, makes any warranty, express or implled, or assumes any legal liability or responsibllity for the accuracy, completeness, or usefulness of any information, apparatus, product or process disclosed, or represents that its use would not infringe privately owned rights.

\section{NOTIICE}

Reference to a company or product name does not imply approval or recommendation of the product by the University of Utah Research Institute or the U. S. Department of Energy to the exclusion of others that may be suit table. 


\section{ABSTRACT}

The Industry Coupled Case Study Program was conceived as a short-term cooperative program between the Federal government and private industry. Federal funds were committed to stimulate geothermal exploration and devel opment between 1977 and 1979, although some work under the program continues into 1982. Federal funding has been phased out and the remaining information developed during the program is being disseminated and reported. This report presents an overview of the program and documents the technical results and open-file data base resulting from the program. 


\section{PART I}

The Department of Energy, Division of Geothermal Energy initiated the Industry Coupled Case Study Program in 1977 in an attempt to accelerate the development of high-temperature resources by private industry. This was part of DOE's overal 1 program to reduce American dependence on foreign energy services and to encourage alternate energy source development. This particular program was designed to of fset high initial development by reducing the financial risks for exploration and reservoir confirmation through costsharing with industry partners. A scientific benefit of the program was envisioned to be in-depth studies of specific areas to aid exploration and development, assess current exploration technology, and to increase general knowledge of geothermal reservoirs. In exchange for government funding, all technical data obtained as part of the contracted exploration programs were released to the Department of Energy to be made public. In addition, a substantial amount and variety of previously existing data generally emphasizing early stage exploration were acquired as part of the program.

Phase I of the Industry Coupled Case Study Program resulted in contracts for work at two major geothermal systems in southwestern Utah. Phase II. included work at 12 high-temperature systems in northern Nevada. Table 1 summarizes all Phase I and Phase II work; a list of the data packages acquired by DOE constitutes Part III of this report.

The Earth Science Laboratory, University of Utah Research Institute (ESL/UURI), perfomed several functions as part of this DOE program under two general headings: 1) technical and management assistance, and 2) data interpretation and publication. As part of the di rect assistance to $D O E$, ESL/UURI personnel have helped write Requests for Proposals and evaluate the proposals from industry as well as monttoring contracts stemming fran proposals and representing DOE as technical speakers in public hearings, proposal briefings, or government liason situations. Additional work consisted of the following: 1) ascertaining that DOE received both quality and quantity of data for the contract; 2) determining that critical but missing or invalid data were purchased to round out an exploration summary of an area or technique; 3 ) if critical data were not in existence, doing what was necessary to create it - such as geologic mapping, or basic surveying for 
aeromagnetic, resistivity and gravity data, or mercury and trace element geochemistry, or potassium-argon age dating and isotope studies for a few examples; 4) establishing a Geothermal Sample Library to store and analyze chips and core from geothermal areas for study by industry scientists, various kinds of national, university, and private laboratories, and by other researchers; 5) working with industry to best determine their needs within the confines of DOE's program to enhance the basic tenet of more rapid geothermal development; 6) keeping DOE aware of the progress of each DOE/Industry contract and of the progress of geothermal development as a viable energy concept; 7) interpreting the data sets from industry and our own work in a state-of-the-art manner to generate additional information for the industry operators, DOE, and the geothermal community as a whole; 8) developing case studies of final results and interpretations for the areas of study; 9) making this plethora of information available to industry, government, geoscientists, and the geothermal community as rapidly as possible to further the development of ideas and techniques.

Prior to the Industry Coupled Case Study Program there was a definite lack of resource knowledge on two levels: 1) on a regional scale, the locations of resources outside of The Geysers field in California were poorly known, and 2) on a site-specific scale, the lateral limits, depth, temperature, product ivity, and longevity of possible resources were little better than guesses. Relatively little surface exploration and drilling had been done by the private sector and the exploration results were held confidential. Several reasons existed: 1) high front-end costs in the form of competitive lease sales, environmental and regulatory delay, and costly exploration and drilling programs; 2) high-risk investment because of the limited geothemal track record, reservoir uncertainties such as temperature, flow rate, resource longevity, corrosion, overall engineering problems; 3 ) competitive energy investments for petroleum, natural gas, uranium and coal; 4) very limited tax incentives; 5) lack of exploration and evaluation techniques and equipment specific to geothermal conditions.

With the cessation of DOE's program comes the realization that, although the program did not overcome many of the obstacles, a great step has been taken towards bettering our understanding on many aspects of this energy source and an infrastructure of knowledgeable scientists, contractors, and 
operators exists. Additionally, there have been advances in leasing, tax incentives, concepts of ownership of geothermal fluids, environmental control measures, loan concepts, equipment, and techniques for exploration and development. Specifically in terms of the Industry Coupled Case Study Program, the following figures vouch for the validity of the program: DOE funds expended - $\$ 14,000,000$; DOE and industry exploration - $\$ 32,000,000$; geoscience data gathered for 14 geothermal reservoirs; 8 integrated case studies completed; over 50 topical reports on various aspects were generated; technique evaluations of 10 methods were carried out; 15 new deep exploration wells were drilled; and 25 drilling histories were completed. Many of the research ideas have been utilized in exploration and development of other forms of energy, such as in the petroleum industry, and the private sector has, indeed, continued its interest in geothemal against all the odds created by reduced restrictions of all kinds for 011 , gas and coal. A recent drilling activities forecast by BDM Corporation for Sandia National Laboratory published in July, 1982 predicts a geothermal drilling and electrical power generation growth that is slow but quite definite (Sandia report 82-7012, pages $2-4)$.

Results from the program may be seen in these deliverables from industry: Drill cuttings, core, fluids Drilling summaries of all $\$ 500,000$ to $\$ 2,000,000$ holes Lithologic, temperature, pressure and geophysical logs Surface studies in geology, geophysics and geochenistry Reservoir tests.

Further results from ESL/UURI have been studies in:

Lithology and petrology

Geochemical and alteration zoning studies

Geologic mapping

Geophysical interpretation

Data integration and case studies

Critical evaluation of techniques and methods.

Much of this information is indicated in Table 1 and the maps of Utah (Phase I) and Nevada (Phase II) showing the locations of the Industry Coupled Program geothermal exploration areas. 

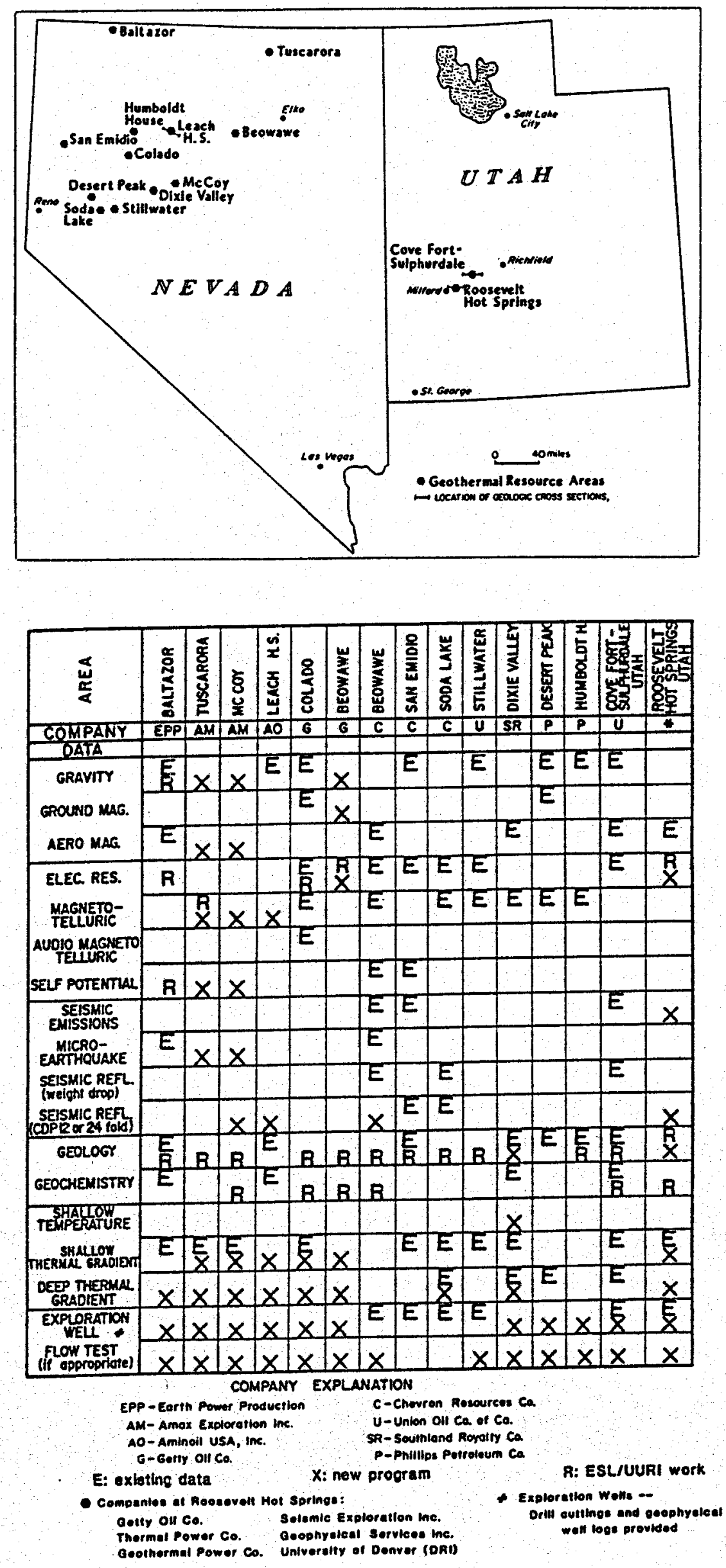

TABLE 1 


\section{PART II}

The following reports, journal articles, and abstracts are divided into two sections: those items which we consider to be a direct result of the Industry Coupled Program; and those items which we consider to have been generated by the program in an indirect manner. Titles and authors are followed by the format in which the item appeared, the date, the Department of Energy number by contract, and the abstract or introduction. 


\section{PART II}

REPORTS CONSIDERED TO BE A DIRECT RESULT OF THE INDUSTRY COUPLED PROGRAM

TITLE - as presented in the present format

AUTHOR(S)

DATE - date is when report was printed and may not reflect the written or delivered date

FORMAT - ESL report designates an origin with the Earth Science Laboratory UUGG designates an origin with the Department of Geology and Geophysics, University of Utah JOURNAL designates an article published by, in press by, or submitted to the scientific journal indicated

REPORT NUMBER - the DOE-designated number by contract and the ESL report number in parentheses

ABSTRACT - abstract, introduction or first page of an article 
ANNOTATED BIBILIOGRAPHY OF THE GEOLOGY OF . THE

ROOSEVELT HOT SPRINGS KNOWN GEOTHERMAL RESOURCE AREA AND THE

ADJACENT MINERAL MOUNTAINS, MARCH 1978

D. Brooks Mckinney

September, 1978

ESL Report

DOE/ET/28392-10 (ESL-10)

\section{INTRODUCTION}

This bibliography is a result of the need to present a unified account of the geologic and geothermal literature of the Roosevelt Hot Springs KGRA in Ut ah. References are compiled to March 31, 1978, and are complete to that date as far as is known.

Since ninety-nine references were found, it seemed worthwhile to append a brief annotation of the contents to provide researchers a starting point for further investigations in the Roosevelt area. Hopefully the annotations will 1 imit the amount of necessary literature search to a minimum in a given type of research.

Additional studies by ESL in the Roosevelt area will assume this Bibliography to be inclusive and will list only pertinent publications and new material published after March 31, 1978. 


\author{
STRATIGRAPHY AND ALTERATION, 15 SHALLOW \\ THERMAL GRADIENT HOLES, ROOSEVELT HOT SPRINGS KGRA AND \\ VICINITY, MILLARD AND BEAVER COUNTIES, UTAH \\ Jeffrey B. Hulen \\ September, 1978 \\ ESL Report \\ DOE/ET/23892-9 (ESL-9)
}

\begin{abstract}
Fifteen shallow themal gradient drill holes were recently completed by Geothermal Power Corporation (GPCR) in the vicinity of the Roosevelt Hot Springs KGRA. Five holes penetrated Tertiary granitic rocks and Precambrian gneiss east of the KGRA. Seven holes completed entirely in alluvium near the southwestern corner of the KGRA encountered a near-surface marker horizon of Pleistocene pumice and perlite. Maximum calculated alluvial sedimentation rates since initial deposition of this pumice and perlite range from 1 foot in 12,500 years to 1 foot in 2,300 years. Three holes east of the Mineral Mountains penetrated late Cenozoic basaltic andesite beneath a thin veneer of alluvium.

Tertiary granitic and Precambrian gneissic bedrock penetrated by the GPCR holes is pervasively but weakly altered. Alteration products in the bedrock consist of trace to minor amounts of clay and sericite after plagioclase and potassium feldspar, chlorite after mafic minerals, and erratically distributed calcite and epidote after plagioclase and leucoxene ( \pm calcite) after sphene. Alluvial grains derived from the bedrock are similarly altered. Unaltered Pleistocene pumice and perlite coexist in the alluvium with altered bedrock grains, indicating that alteration in these grains antedates alluvial deposition and therefore antedates the presently active geothermal system.

Calcite cement is abundant in nearly all alluvium penetrated by the GPCR holes. In several of the holes at the southwestern corner of the KGRA, much of the alluvium seems to have been firmly indurated by the cement. This cemented al luvium may function locally as a caprock preventing fluid and heat loss from the active geothermal system.

Manganese and iron oxides occur in highly variable amounts in samples from all the GPCR holes. Dendritic films and crusts of manganese oxide in alluvium postdate carbonate cement and may be genetically related to the presently active geothemal system. Disseminated and veinlet-controlled manganese oxide in bedrock is of uncertain age relative to the geothermal system. Most of the iron oxides were formed after sample collection by oxidation of drill steel and of steel lids on sample jars.
\end{abstract}

All 15 GPCR drill holes appear to be peripheral to a central zone of anomalously high thermal gradient and low resistivity delineated by previous investigations. GPCR -8 and -14 , however, are characterized by high heat flow 
and relatively abundant manganese oxide mineralization, which may reflect a favorable hydrologic system controlling thermal fluid flow at depth. These holes thus seem most encouraging for discovery of a deeper high-temperature geothermal resource. 


\title{
GEOLOGY OF ROOSEVELT HOT SPRINGS KGRA, BEAVER COUNTY, UTAH
}

\author{
D. L. Nielson \\ B. S. Sibbett \\ D. B. Mckinney \\ J. B. Hulen \\ J. N. Moore \\ S. M. Samberg
}

December 1978

ESL Report

DOE/ET/28392-19 (ESL-12)

\section{ABSTRACT}

The Roosevelt Hot Springs KGRA is located on the western margin of the Mineral Mountains in Beaver County, Utah. The bedrock geology of the area is presented in this report. It is dominated by metamorphic and plutonic rocks of Precambrian age as well as felsic plutonic phases of the Tertiary Mineral Mountains Pluton. Rhyolite flows, domes, and pyroclastics reflect igneous activity between 0.8 and 0.5 million years ago. All lithologies present in the map area are described in detall with an emphasis on characteristics which will allow them to be distinguished in drill cuttings.

The geothermal system at Roosevelt Hot Springs KGRA is structurally controlled with reservoir rocks demonstrating little primary permeability. The structure is mainly a result of low-angle normal faulting which has produced low-angle, westward dipping mylonites, steeply dipping, northwesttrending mylonites, and brecciation localized in the hanging wall of the principal low-angle fault. These mylonites are up to $15 \mathrm{~m}$ thick and they are silicified and retrograded to greenschist facies assemblages. East-west faulting is also present and has been produced by deep-seated regional zones of weakness. North to north-northeast-trending faults are the youngest structures in the area, and they control present fumarolic activity and recent hot spring activity which has deposited opaline and chalcedonic sinters. It is proposed here that the geothemal reservoirs are controlled primarily by intersections of the principal zones of faulting. This conclusion is supported by the configurations of the fault patterns. It indicates the importance of regional geologic mapping and structural analys is in the exploration for hydrothermal resources.

Logs from Thermal Power Utah State 72-16, Getty 0il State 52-21, and six shal low thermal gradient holes drilled by the University of Utah are presented in this report and have been utilized in the construction of geologic cross sections of the geothermal field. 
GEOLOGY OF THE COVE FORT-SULPHURDALE KGRA

J. N. Moore

S. M. Samberg

B. S. Sibbett

May 1979

ESL Report

DOE/ET/28392-27 (ESL-18)

\section{ABSTRACT}

The Cove Fort-Sulphurdale known Geothermal Resource Area (KGRA) is located on the northwestern margin of the Marysvale volcanic field in southwestern Utah. The geology of the KGRA is dominated by 1 ava flows and ash-flow tuffs of late oligocene to mid-Miocene age that were deposited on faulted sedimentary rocks of Paleozoic to Mesozoic age. The rocks of the Cove Fort-Sulphurdale area were metamorphosed and mineralized by stocks of quartz monzonite and latite porphyry during the lower Miocene. An unrel ated hydrothermal event produced small fluorite deposits near Cove Fort. Quaternary volcanic activity produced extensive andesitic basalt flows along the western margin of the KGRA.

The geothermal system of the Cove Fort-Sulphurdale KGRA is structurally controlled by normal faults. The principle structures include: northnorthwest and northeast-trending steeply dipping faults and low-angle westdipping faults. The low-angle faults bound large-scale gravitational glide blocks in the central part of the Cove Fort-Sulphurdale area. High-angle faults control fluid flow within the geothermal reservoir, while the. gravitational glide blocks provide an impermeable cap for the geothermal system in the central part of the field.

Surficial activity occurring to the north and south of the glide blocks is characterized by the evolution of hydrogen sulfide and deposition of native sulfur. Intense acid alteration of the alluvium, resulting from downward migration of sulfuric acid, has left porous siliceous residues that retain many of the original sedimentary structures. The acid-altered areas are concentrated along mineralized, steeply dipping faults. It is suggested that the intense low magnitude earthquake activity in the cove Fort area reflects reactivation of older faults.

This report includes detailed logs of Union 011 Company drill holes Forminco \#1, Utah State 42-7, and Utah State 31-33. 
MULTIELEMENT GEOCHEMICAL EXPLORATION DATA FOR THE

COVE FORT-SULPHURDALE KNOWN GEOTHERMAL RESOURCE AREA

BEAVER AND MILLARD COUNTIES, UTAH

R. W. Bamford

0. D. Christensen

September 1979

ESL Report

DOE/ET/28392-28 (ESL -19)

\section{ABSTRACT}

Multielement geochemical exploration data have been acquired for the Cove Fort-Sulphurdale known Geothermal Resource Area (KGRA). This was accomplished by analys is of both whole rock and +3.3 specific gravity concentrate samples from cuttings composites collected from shallow rotary drill holes. Areal distributions are reported for arsenic, mercury, lead and zinc. These are elements indicated by previous studies to be broadly zoned around thermal centers in geothermal systems and thus to be useful for selecting and prioritizing drilling targets.

Results from this work suggest that reservoir temperature and/or reservoir-to-surface permeability, and thus possibly overall potential for a geothemal resource, increase northward beneath the approximately 18 square. mile area containing shallow drill holes, possibly to beyond the northern limits of the area. The data provide a basis for development of three principal target models for the geothermal system but do not permit prioritization of these models. It is recommended that geochenical, geological, and temperature gradient surveys be expanded northward from the present survey area to more fully define the area which appears to have the best resource potential and to aid prioritization of the target models. 


\section{GEOLOGY MAP OF THE SAN EMIDIO \\ GEOTHERMAL AREA \\ Joseph N. Moore \\ December, 1979}

ESL Report

DOE/ET/28392-33 (ESL-23)

\section{INTRODUCTION}

The San Emidio geothermal area is adjacent to the northern end of the Lake Range, approximately 15 mi les south of Gerlach, Nevada (Figure 1). The Lake Range foms a tilted block, bounded on the west by steeply dipping Basin and Range faults. Associated with one of these faults are hydrogen sulfide seeps, acid alteration, and hot water wells, indicative of an active geothermal system (Garside, 1979).

During the mid-1970s, Chevron Resources Company initiated a broad-based exploration program of the San Emidio geothermal area that included detailed geophysical studies and deep exploratory drilling. The ongoing interpretation of these data by the Earth Science Laboratory as part of the Department of Energy/Division of Geothermal Energy's Industry Coupled Case Studies Program point out the need for additional geologic mapping, particularly on the eastern margin of the San Emidio Desert. This report summarizes our reconnaissance geologic work in this area. 


\section{GEOLOGY OF THE SODA LAKE GEOTHERMAL ARE}

Bruce S. Sibbett

December, 1979

ESL Report

DOE/ET/28392-34 (ESL-24)

\section{ABSTRACT}

The Soda Lake geothermal area is located in the Carson Desert, westcentral Nevada. Hot springs activity has occurred in the Soda Lake area in the past, resulting in surface deposits which have motivated present geothermal exploration. The geothermal anomaly is in Quaternary clastic sediments which are as much as 4600 feet thick. The sediments consist of interbedded deltaic, lacustrine, and alluvial sediments.

Quaternary basaltic igneous activity has produced cinder cones, phreatic explosions that formed maar occupied by Soda Lake, and possible dikes.

Opal deposition and soil alteration are restricted to a small area two miles north of Soda Lake. The location of hot springs activity and the surface themal anomaly may be partially controlled by north-northeasttrending faults. 


\section{INTERPRETATION OF ELECTRICAL RESISTIVITY AND SHALLOW SEISMIC \\ REFLECTION PROFILES, WHIRLWIND VALLEY AND HORSE HEAVEN \\ AREAS, BEOWAWE KGRA, NEVADA}

Christian Smith

December, 1979

ESL Report

DOE/ET/28392-35 (ESL-25)

\section{ABSTRACT}

Numerical modeling and analysis of surface electrical and seismic data from the Beowawe KGRA, north-central Nevada, permit extrapolation of mapped geologic units and structures to approximately a mile $(1.6 \mathrm{~km})$ depth from which inferences about the geothermal system can be made. Detailed numerical modeling was completed for 78 line-mi. (125 km) of dipole-dipole resistivity data and includes compensation for topographic effects caused by the Malpais Rim scarp. The interpreted sections have as many as five distinct electrical units, one of which occurs only within the area of hydrothermal alteration along the fault set at the base of the Malpais Rim. The weight-drop seismic reflection data show numerous normal faults sub-parallel to the Malpais Rim within Whirlwind Val ley west and southwest of The Geysers.

A $1,5000 \mathrm{ft}(450 \mathrm{~m})$ thick zone of low resistivity at the surface northeast of The Geysers deepens to $2,000 \mathrm{ft}(600 \mathrm{~m})$ bel ow the surface at the two Chevron Resource Co. exploration wells southwest of The Geysers. This suggests that the post-Miocene east-northeast fault set at the base of the Maipais Rim is not a conduit for hot water at shallow depths to the southwest of The Geysers. The north-northwest-striking Miocene Dunphy Pass fault zone, immediately east of The Geysers, does display low resistivities at depths greater than $2,000 \mathrm{ft}(600 \mathrm{~m})$ and may provide a deep-seated path for upwelling geothermal water to the Malpais Rim fault set.

A widespread conductive anomaly in Horse Heaven appears to be distinct from the anomaly at The Geysers. The resistivity interpretation cannot determine whether this three- by two-mile area $(5 \times 3 \mathrm{~km})$ represents a thick sequence of rock saturated with hot water, or carbonaceous or altered units within the Ordovician Valmy formation. Any vast, deep geothermal reservoir lies below the depth of resolution of these surveys. 
GEOLOGY AND ALTERATION OF THE BALTAZOR HOT SPRINGS

AND PAINTED HILLS THERMAL AREAS, HUMBOLDT COUNTY, NEVADA

Jeffrey B. Hulen

December, 1979

ESL Report

$D O E / E T / 28392-36(E S L-27)$

\section{ABSTRACT}

The Baltazor Hot Springs KGRA and nearby Painted Hills thermal area are situated in Humboldt County, northwestern Nevada along the northwestern margin of the Basin and Range province.

The oldest rocks exposed in the Baltazor area are eugeosynclinal metasedimentary and subordinate metavolcanic rocks of Permain to Triassic(?) age intruded by Cretaceous diorite and quartz diorite. These are overlain by a thick volcanic and volicaniclastic sequence of Miocene through Pliocene age. Pre-Tertiary rocks are not exposed in the Painted Hills. Here, only Miocene to Pliocene volcanics and volcaniclastics crop out, and only the youngest of these can be confidently correlated with rocks of similar age and character in the Baltazor area.

Principal structures in the Baltazor area are intersecting high-angle normal faults which trend northerly and northwesterly. Quaternary landsiides are dominant in the Painted Hills, although northerly- and northwesterlytrending high-angle faults are present.

Hydrothermal alteration and mineralization at Baltazor and in the Painted Hills are of several different styles and ages. Copper-bearing quartz veins in pre-Tertiary rocks antedate Cenozoic volcanism and sedimentation. Widespread argillization, silicification, hematization and local mercury mineralization in the Painted Hills are probably pre-Pleistocene in age, even though coincident with a contemporary thermal anomaly. Small calcite-bearing opaline sinter deposits at Baltazor Hot Springs are probably genetically related to chalcedony-calcite veins in adjacent mid-Miocene volcanics and Quaternary landslide debris.

Baltazor Hot Springs and associated thermal phenomena and alteration are controlled by the intersection of northerly- and northwesterly-trending highangle normal faults. The Painted Hills thermal anomaly and alteration may be controlled both by high-angle faults and permeable Tertiary volcanic and volcaniclastic horizons. The heat source for thermal phenomena and alteration in both areas is probably deep fault-controlled fluid circulation coupled with an abnormally high regional thermal gradient. 


\title{
A STRATEGY OF EXPLORATION FOR HIGH TEMPERATURE HYDROTHERMAL \\ SYSTEMS IN THE BASIN AND RANGE PROVINCE
}

\author{
S. H. Ward \\ H. P. Ross
}

D. L. Nielson

December 1979

ESL Report

DOE/ET/27002-5 (ESL-22)

\begin{abstract}
A fifteen-phase strategy of exploration for high-temperature convective hydrothermal resources in the Basin and Range province, recommended herein, features a bal anced mix of geological, geochemical, geophysical, hydrological, and drilling activities. The strategy is based on a study of data submitted under the Department of Energy's Industry Coupled Case Study Program. Justification for inclusion in or exclusion from the strategy of all pertinent geoscientific methods is given. With continuing research on methods of exploration for and modeling of convective hydrothermal systems, this strategy is expected to change and become more cost-effective with time. Variations on the basic strategy are to be expected where the geology or hydrology requires it. Personal preferences, budgetary constraints, time and land position constraints, and varied experience may cause industrial geothermal exploration managers to differ with our strategy. For those just entering geothermal exploration, the strategy is expected to be particularly useful.
\end{abstract}




\author{
NUMERICAL MODELING AND INTERPRETATION \\ OF DIPOLE-DIPOLE RESISTIVITY AND IP PROFILES \\ COVE FORT-SULPHURDALE KGRA, UTAH \\ Howard P. Ross \\ December, 1979 \\ ESL Report
}

DOE/ET/28392-37 (ESL-26)

\title{
ABSTRACT
}

The Cove Fort-Sulphurdale known Geothermal Resource Area (KGRA) is located near the junction of the Pavant Range and the Tushar Mountains in south-central Utah. The area has been the site of an intensive geothermal exploration effort by Union 0il Company since 1975. This report presents the electrical resistivity data obtained by Union 0il Company and a subsequent survey conducted for the Earth Science Laboratory, and a detailed numerical interpretation of both data sets.

The detailed modeling pemits a characterization of the intrinsic electrical resistivity to depths exceeding 2,000 feet. An area of over two square miles with bulk in-situ resistivities of four-to-five ohm-m is delineated at Sulphurdale near the Union 011 Co. well CFSU \#42-7. The lowresistivity rocks define the area of extensive hydrothermal alteration in response to the presence of clay minerals and conductive thermal fluids. In contrast the area north and east of Cove Fort is typified by high (100-300 ohm-m) resistivities to depths exceeding 2,000 feet. This is an area of Cretaceous and Paleozoic sedimentary rocks where two attempts to drill to reservoir depth failed because of extreme drilling problems. The high resistivities are not considered encouraging for the presence of a deeper reservoir. The electrical resistivity interpretation has defined several areas of probable upward migration of thermal fluids along north-trending normal faults. Some of these areas may have potential for direct heat geothermal utilization.

Two lines of induced polarization data indicate large volumes of Cretaceous and Paleozoic sedimentary rocks may be mineralized with one- to two-weight percent sulfides. Geologic studies indicate much of this minerarization predates the present geothermal system. 


\title{
INTERPRETATION OF
}

\author{
WELL LOG DATA FROM FOUR DRILL HOLES AT \\ ROOSEVELT HOT SPRINGS KGRA \\ W. E. Glenn \\ J. B. Hulen \\ December, 1979 \\ ESL Report
}

DOE/ET/28392-38 (ESL-28)

\section{ABSTRACT}

Well logs fran four drill holes, Utah State Geothermal Wells 14-2, 52-21 and 72-16 and Geothermal Power Corporation's thermal gradient hole GPC-15 have been digitized, plotted and studied. This study had three objectives: 1) to present the well $10 \mathrm{~g}$ data in a convenient format for easy study, 2) to determine the nature of the geothemal reservoir rock and fluid properties, and 3) to make some inference on fluid entry locations in the boreholes and their effect on heat flow.

The al luvium, which varies in thickness from 160 . feet $(49 \mathrm{~m})$ at $72-16$ to over 1900 feet $(580 \mathrm{~m}, T D)$ at GPC-15, exhibits compaction and cementation with depth. Bulk density increases and porosity decreases with depth, from 2.28 to $2.46 \mathrm{gm} / \mathrm{cc}$ and from $23 \%$ to $15 \%$, respectively, between 558 and 1898 feet (170$579 \mathrm{~m})$, which is bel ow the interpreted water table at 540 feet $(165 \mathrm{~m})$. Over the same interval, the acoustic velocity increases from $8200 \mathrm{ft} / \mathrm{sec}(2.5$ $\mathrm{km} / \mathrm{sec}$ ) to about $14,000 \mathrm{ft} / \mathrm{sec}(4.3 \mathrm{~km} / \mathrm{sec})$ at the bottom of the hole. Above the water table the bulk density varies considerably, but averages approximately $2.05 \mathrm{gm} / \mathrm{cc}$.

Bedrock in Utah State 14-2 and 52-21, various granitic intrusives and mafic to granitic gneisses, exhibits highly variable $10 \mathrm{~g}$ properties throughout the length of the holes. The log responses have been interpreted in terms of lithologic effects peculiar to igneous and metamorphic rocks. Dense, hydrousmafic mineral contributions can be identified in acoustic, density and neutron logs. Acoustic velocities vary between 15,500 and $22,000 \mathrm{ft} / \mathrm{sec}(4.7$ and 6.7 $\mathrm{km} / \mathrm{sec}$ ). Bulk densities vary between 2.5 and $2.8 \mathrm{gm} / \mathrm{cc}$; resistivities vary from 40 to greater than 2000 ohm-m, and neutron porosities vary between nearly zero to 15\%. Lower velocity, density and resistivity and higher neutron porosity are fracture-related values and occur above 2000 to 3000 feet (610$915 \mathrm{~m}$ ) in both holes. Potentially permeable and possibly related production zones correspond to these log responses, correlate with fractures, and occur primarily in the upper levels of each hole. However, permeability in 52-21 is quite low and the hole is considered a non-producer.

The temperature logs and gradients computed from these logs have been used to examine heat flow in the vicinity of the four drill holes. Assumed and calculated thermal conductivities have been used in the analyses, 4 
$\mathrm{mcal} / \mathrm{cm}{ }^{\circ} \mathrm{C}$ sec for the al luvium and $7 \mathrm{mcal} / \mathrm{cm}{ }^{\circ} \mathrm{C}$ for the crystalline rocks. The data indicate that $14-2$ and $72-16$ reside in a dominantly convective heat fl ow enviroment, whereas GPC-15 and 52-21 reside in a daminantly conductive heat flow enviroment. The convective regions are believed to be fracture controlled and only portions of each hole reside totally in a convective region; in each case it is the upper bedrock portion of the hole. In every case the alluvium or upper portion of the alluvium acts as a thermal blanket over the systen. Maximum heat flow among the holes, $40 \mu \mathrm{cal} / \mathrm{cm}^{2} \mathrm{sec}$, occurs in the vicinity of 72-16 and the lowest heat flow, $4 \mu \mathrm{cal} / \mathrm{cm}^{2} \mathrm{sec}$, in the vicinity of GPC-15. 


\title{
OELINEATION OF AN ELECTRICAL RESISTIVITY ANOMALY, \\ MALPAIS AREA, BEOWAWE KGRA, EUREKA AND LANDER COUNTIES, NEVADA
}

\author{
Christian Smith
}

July, 1980

ESL Report

DOE/ID/12079-10 (ESL-40)

\section{ABSTRACT}

The Beowawe Geysers hydrothermal system discharges near the base of an east-west-trending Basin and Range fault approximately $50 \mathrm{~km}$ east of Battle Mountain, Nevada. The upthrown block south of The Geysers is called the Malpais. Exposures 2-3 km east of The Geysers reveal a segment of the eastern boundary of a major north-northwest-trending Miocene graben. The Geysers are located along the margin of the graben near its intersection with the Basin and Range fault.

A simple numerical model of previously released bipole-dipole resistivity data shows the margin of the graben to be anomalously conductive below the Malpais. The conductive area has been delineated with data from a dipoledipole resistivity survey run in April, 1980 for this study. Detailed numerical models of these data define a $1250 \mathrm{~m}$ wide body with resistivities less than 20 ohm-m that appear to connect The Geysers and the graben boundary. The minimum depth to the conductor is interpreted to be $375 \mathrm{~m}$; its depth extent is undetermined.

The el ectrical data do not resolve whether the anomaly below the Malpais may be the product of a defunct hydrothermal system or the signature of an active system. If thermal gradient data detect an enhanced heat flow anomaly in the same area, the Malpais may be a viable geothermal exploration target within the Beowawe KGRA. 


\section{GEOCHEMISTRY OF THE COLADO GEOTHERMAL AREA, PERSHING COUNTY NEVADA}

Odin D. Christensen

July, 1980

ESL Report

DOE/ID/12079-9 (ESL-39)

\section{ABSTRACT}

Multielement geochemical analys is of drill cuttings from 18 shallow and 2 intermediate-depth temperature gradient holes outlines an area of anomalous geochemistry related to the fluid flow and temperature distribution within the Colado geothermal area. The concentrations of $\mathrm{Hg}, \mathrm{As}, \mathrm{Li}$, and Be belong to more than one statistical population and provide the clearest expression of hydrothermal processes. Enrichments of these four elements define anomalous zones which are spatial iy coincident with a measured temperature anomaly. The spatial distribution suggests that thermal fluid rises into alluvium in the vicinity of a major Basin and Range fault to depths of 200-400 feet $(60-120$ $\mathrm{m})$, then flows laterally within shallow alluvial aquifers down the local hydrologic gradient. As the fluid cools, $\mathrm{Li}, \mathrm{Be}, \mathrm{As}$, and $\mathrm{Hg}$ are deposited in response to changing physical and chemical conditions. As and Be appear to be deposited early in higher temperature zones; Li begins to deposit early but forms a rather dispersed geochemical anomaly; $\mathrm{Hg}$ is anomalous throughout the entire geothermal area but is concentrated in a shallow halo above the As and Be anomalies. The distributions suggest that the entry of thermal fluids from depth into the alluvium is spatially restricted to a small area and that the larger area of the observed thermal anomaly is due to the flow of warm fluid wi thin shal low aquifers. 
GEOLOGY OF THE COLADO GEOTHERMAL AREA

\author{
PERSHING COUNTY, NEVADA \\ Bruce S. Sibbett \\ Michael J. Bullett \\ JuTy, 1980 \\ ESL Report \\ DOE/ID/12079-8 (ESL-38)
}

\begin{abstract}
The Colado geothermal area in south-central Pershing County, Nevada is defined by hot water wells in alluvium just west of the West Humboldt Range. Geothermal gradient holes have encountered temperatures up to $113.5^{\circ} \mathrm{C}$ at a depth of $76 \mathrm{~m}(250 \mathrm{ft})$ with a gradient reversal in the alluvium below this depth.
\end{abstract}

The West Humboldt Range consists mainly of Triassic to Jurassic slaty shale to quartzite of the Auld Lang Syne Group. Carbonate rocks of the Jurassic Lovelock Formation have been thrust over pelitic rocks on the south end of the area. Erosional remnants of Tertiary tuffs and sediments overlay the metasediments in the West Humboldt Range.

The principal structures are high-angle faults striking north-northwest, northeast and north-south. The horst-to-graben transition along the rage front consists of several step faults trending irregularly north. The structural pattern in the west edge of the range probably continues to the west under the Quaternary alluvium where the source of the hot water is located. Themal waters probably rise al ong a major fault intersection in the Mesozoic rocks then spread out in an aquifer in the alluvium. Several thrust faults are exposed south of Coal Canyon, and a structural break in the Mesozoic rock exists under the canyon. Several low-angle faults are present north of Coal Canyon but their effect, if any, on the geothermal occurrence is not known. 
THE GEOLOGY OF THE BEOWAWE GEOTHERMAL SYSTEM, EUREKA AND LANDER COUNTIES, NEVADA

Eric M. Struhsacker

July, 1980

ESL Report

DOE/ID/12079-7 (ESL-37)

\section{ABSTRACT}

This report describes a geologic study undertaken to evaluate the nature of structural and stratigraphic controls within the Beowawe geothermal system, Eureka and Lander Counties, Nevada. The study is part of a comprehensive ongoing case study of the Beowawe geothermal system sponsored by the Division of Geothermal Energy of the Department of Energy under the Industry Coupled Program. This study includes geologic mapping at a scale of 1:24,000 and lithologic logs of deep Chevron wells.

Two major normal fault systems control the configuration of the Beowawe geothermal system. Active hot springs and sinter deposits lie along the Malpais Fault zone at the base of the Malpais Rim. The Malpais Rim is one of several east-northeast-striking, fault-bounded cuesta in north-central Nevada. A steeply inclined scarp slope faces northwest towards Whirlwind Valley. The general inclination of the volcanic rocks on the Malpais dip sl ope is $5^{\circ}$ to $10^{\circ}$ southeast.

The Malpais scarp slope exposes normal faults on a northwest trend that predate the development of the Malpais scarp. An 0ligocene to Miocene graben, presently confining the known geothermal system, developed along this trend. The north-northwest-trending Dunphy Pass Fault zone east of the sinter terrace is the eastern boundary of the graben. The western boundary of the graben appears to cross the Malpais Rim in Horse Heaven but is poorly exposed. A $1200 \mathrm{~m}$-thick section of Miocene basaltic, andesite, dacite, and basalt flows accumulated within the developing graben and covered a middle Tertiary sequence of tuffaceous sediments, tuffs, and andesite flows, and the subjacent Ordovician Valmy Formation.

The Malpais Fault zone developed after the eruption of the Miocene volcanics; the normal faults controlling the scarp primarily strike eastnortheast to east-west. However, these faults def ine two flexures in the overall east-northeast-trend of the Malpais Rim; The Geysers occur at one of these flexures. A set of steeply-dipping east-northeast and east-westtrending faults controlling the Malpais Rim scarp slope apparently carry hot fluid to the surface. Northwest and west-northwest-trending vertical faults may limit the northeastern and southwestern extent of modern surficial thermal activity. The intersections of these faults and the Malpais fault may serve as deep conduits for the geothermal system. At the southwest end of the terrace, the Maipais scarp curves to the southwest, whereas elements of the east-northeast fault set appear to continue westward into the valley, creating 
a subtle horst-like structure and permitting the westward migration of thermal fluids.

The deep Ginn and Rossi wells penetrate the Tertiary volcanics and the Valmy Formation. Hydrothermal alteration minerals in these wells are vertically zoned from a clay-calcite-quartz-pyrite assemblages above $600 \mathrm{~m}$ $(2000 \mathrm{ft})$ of depth to a quartz-calcite-mixed chlorite and clay-pyritesericite-epidote assemblage bel ow $1400 \mathrm{~m}$ (4500 ft). Alteration intensity is variable due to varying fracture and lithologic permeabilities and diverse lithologic compositions.

The faults controlling the Malpais scarp also served as conduits for hydrothermal fluids earlier in the evolution of the scarp. Uplift along the Malpais scarp within and east of the Dunphy Pass fault zone exposes the Valmy Formation and a swarm of chalcedony-carbonate veins. Broad areas of silicification, argillization, and brecciation invade the Valmy formation and the Miocene volcanics. The intersection of these two major fault zones is, perhaps, a deep conduit for modern themal fluids. A zone of anomalously low resistivity extends from the surface at the modern sinter terrace to $999 \mathrm{~m}$ $(3000 \mathrm{ft})$ of depth within the Dunphy Pass Fauit zone. The silicified zone presently appears to divert fluid laterally to the modern hot springs. Permeable zones of fractured Valmy Formation and volcanic rocks probably serve as satellite reservoirs at shallow to intermediate depths.

Regional heat flow data indicate that circulation of fluid to a deep reservoir is necessary to explain the high measured temperatures of $214^{\circ} \mathrm{C}$ encountered at a depth of $2880 \mathrm{~m}$ (9460 ft) in the Ginn well. Geologic evidence is inadequate to determine if the deep reservoir resides in the siliceous rocks of the Roberts Mountains thrust or within deeper carbonates. 
INTERPRETATION OF A DIPOLE-DIPOLE ELECTRICAL RESISTIVITY SURVEY, COLADO GEOTHERMAL AREA, PERSHING COUNTY, NEVADA

\author{
Claron E. Mackelprang \\ September, 1980 \\ ESL Report \\ DOE/ID/12079-11 (ESL-41)
}

\title{
ABSTRACT
}

An electrical resistivity survey in the Colado geothermal area, Pershing County, Nevada has defined areas of low resistivity on each of five lines surveyed. Some of these areas appear to be fault controlled. Thermal fluids encountered in several drill holes support the assumption that the hot fluids may be associated with areas of low resistivity. The evidence of faulting as interpreted from modeling of the observed resistivity data is therefore particularly significant since these structures may be the conduits for the thermal fluids.

Sub-al luvial fault zones are interpreted to occur between stations 0.5 NW on Line $D$ and on Line $A$ between stations 4 NW and 4 SE. Fault zones are al so interpreted on Line C near stations $1 \mathrm{NW}, 1 \mathrm{SE}$, and $3 \mathrm{SE}$, and on Line $E$ between stations 2-4 NW and $1 \mathrm{SE}$. No faulting is evident under the alluvial cover on the southwest end of Line B.

A deep conductive zone is noted within the mountain range on two resistivity lines. There is no definite indication that thermal fluids are associated with this resistivity feature. 
COMPUTER SYSTEM FOR DIGITIZING,

\author{
ANALYZING AND PLOTTING WELL LOG DATA \\ (A USER'S GUIDE TO WELLOG.REV.1) \\ J. W. Atwood \\ T. J. Killpack \\ W. E. Glenn \\ March, 1980
}

ESL Report

DOE/ID/12079-1 (ESL-31)

\title{
ABSTRACT
}

WELLOG is a system of programs developed at the Earth Science Laboratory to be used to digitize well logs and perform some analysis and plotting of the data. Multiple logs can be plotted side by side for correlation analysis and up to three logs can be plotted in a cross plot. Data entry and editing functions are also provided by the programs. This system of well 109 interpretation programs is presently operating on the University of Utah UNIVAC 1108 computer. Digitizing of well logs is accomplished by an old model CALMA (off-line) digitizer. Those part of WELLOG that handle the digitized data tapes are extremely machine dependent. The parts of WELLOG that produce the plots and handle the data beyond the digitized data tape are more portable. 
GEOLOGY OF THE CENTRAL MINERAL MOUNTAINS

BEAVER COUNTY, UTAH

Bruce S. Sibbett

Dennis L. Nielson

March, 1980

ESL Report

DOE/ET/28392-40 (ESL-33)

\section{ABSTRACT}

The Mineral Mountains are located in Beaver and Millard Counties, southwestern Utah. The range is a horst located in the transition zone between the Basin and Range and Colorado Plateau (Stokes, 1977) geologic provinces. A multiple-phase Tertiary pluton forms most of the range, with Paleozoic rocks exposed on the north and south and Precambrian metamorphic rocks on the west in the Roosevelt Hot Springs KGRA (Known Geothermal Resource Area). Precambrian banded gneiss and Cambrian carbonate rocks have been intruded by foliated granodioritic to monzonitic rocks of uncertain age.

The Tertiary pluton consists of six major phases of quartz monzonitic to leucocratic granitic rocks, two diorite stocks, and several more mafic units that form dikes.

During uplift of the mountain block, overlying rocks and the upper part of the pluton were partially removed by denudation faulting to the west. The interplay of these low-angle faults and younger northerly trending Basin and Range faults are responsible for the structural control of the Roosevelt Hot Springs geothermal system. The structural complexity of the Roosevelt Hot Springs KGRA is unique within the range, although the same tectonic style continues throughout the range.

During the Quaternary, rhyolite volcanism was active in the central part of the range and basaltic volcanism occurred in the northern portion of the map area. The heat source for the geothermal system is probably related to the Quaternary rhyolite volcanic activity.

This study did not document any additional evidence of recent geothermal activity. It has, however, documented several areas of young basaltic volcanism in the northern portion of the Mineral Mountains. In addition, a structural framework has been developed which will be of use to geothermal explorationists working in the area. 


\title{
A LIGHT STABLE ISOTOPE STUDY OF THE ROOSEVELT HOT SPRINGS THERMAL AREA, SOUTHWESTERN UTAH \\ David T. Rohrs \\ John R. Bowman \\ May, 1980 \\ UUGG Report
}

DOE/ET/28392-46

\begin{abstract}
The isotopic composition of hydrogen, oxygen, and carbon has been determined for regional cold springs, thermal fiuids, and rocks and minerals from the Roosevelt Hot Springs thermal area. The geothermal system has developed within plutonic granitic rocks and amphibolite facies gneiss, relying upon fracture-controlled permeability for the migration of the thermal fluids. Probably originating as meteoric waters in the upper elevations of the Mineral Mountains, the thermal waters sampled in the production wells display an oxygen isotopic shift of at least +1.2 . Depletions of $\delta^{18} 0$ in whole rock, K-feldspar, and biotite have a positive correlation with alteration intensity. W/R mass ratios, calculated from the isotopic shifts of rock and water, range up to 3.0 in a producing horizon of one well, although the $K$-feldspar has experienced only 30 percent exchange with the thermal waters. While veinlet quartz has equilibrated with the thermal waters, the 180 values of $K-m i c a$ clay, an al teration product of plagioclase, mimic the isotopic composition of $\mathrm{K}$-feldspar and whole rock. This suggests that locally small W/R ratios enable plagioclase to influence its alteration products by isotopic exchange.
\end{abstract}

oxygen-isotope temperatures based on observed $\delta^{18} 0$ values of calcite and an assumed constant $\delta 180$ value of thermal fluid are erratic and significantly lower than measured thermal gradients or fluid inclusion filling temperatures. This lack of agreement is the result of our assumption of a constant oxygen isotopis composition of thermal fluid at all levels within the system. Rather, the $\delta^{18} 0$ values of calcite indicate enrichment of the thermal water with $\delta^{18} 0$ in weakly altered rocks, probably from isotopic exchange under low W/R ratios and slow circulation rates in relatively impermeable rocks. These complications indicate that casual application of mineral isotope thermometers without consideration of potential variations in fluid isotopic composition can lead to misinterpretation. The calcite, like the K-mica, may al so be influenced by the host plagioclase. The systematic increase in $\delta^{13} \mathrm{C}$ values of calcite, generally from -6.0 to -2.4 approaching shallower depths, can be reproduced by two separate models. Each model requires the interaction of the three components of the carbon reservoir: $\mathrm{CO}_{2}(\mathrm{~g})$, fluid $\left(\mathrm{H}_{2} \mathrm{CO}_{3}\right.$ app $\left.+\mathrm{HCO}_{3}\right)$, and calcite. Precipitation of calcite modifies the $\delta^{13} \mathrm{C}$ of $\mathrm{CO}_{2}^{2}(\mathrm{~g})$ and fluid and provides a decrease in the molality of the total dissolved carbonate which is consistent, with the decrease in molality predicted by mineral equilibria. The ${ }^{13} C$ of the total carbon reservoir is 
between -4.5 and -5.8 . It is not possible to unambiguously assign a carbon source to these values.

The small isotopic shift of the thermal waters, the small extent of exchange experienced by the rocks in the production zone, and the enriched ${ }^{118} 0$ values of $K-m i c a$ clay attest to the lack of communication between the rock and the bulk of the thermal waters. the circulation of the thermal water is evidently restricted to permeable fracture zones with little infiltration into the surrounding impermeable rocks, accounting for the variabilities in alteration and $W / R$ ratios. However, a lack of systematically collected core samples has precluded closer definition of the processes responsible for these characteristics. 


\author{
GEOCHEMISTRY OF SERICITE AND CHLORITE IN WELL 14-2 \\ ROOSEVELT HOT SPRINGS GEOTHERMAL SYSTEM AND IN \\ MINERAL-IZED HYDROTHERMAL SYSTEMS \\ Judith M. Ballantyne \\ June, 1980 \\ UUGG Report
}

DOE/ET/28392-43

\title{
ABSTRACT
}

Chemical compositions of chlorite and sericite from one production well in the Roosevelt geothermal system have been determined by electron probe methods and compared with compositions of chlorite and sericite from porphyry copper deposits. Modern system sericite and chlorite occur over a depth interval of $2 \mathrm{~km}$ and a temperature interval of $250^{\circ} \mathrm{C}$.

Mineral compositional variation within samples of cuttings from individual depth intervals from the geothemal well is as large as that between samples, and is sufficiently large to obscure any effects related to present day hot water entry zones, at least on the scale sampled. Recent suggestions are that the well may have been drilled parallel and close to a major fluid-bearing fracture, and if so would not provide a good test situation. Sericites range between illites and muscovites on the basis of $k$ and Si content. Chlorites are ripidolites, brunsvigites and pycnochlorites. Sericite compositional ranges are 0.6 to $1.0 \mathrm{~K}, 3.1$ to $3.5 \mathrm{si}, 0.0$ to $0.3 \mathrm{Fe}$, 0.0 to $0.3 \mathrm{Mg}$ and 1.7 to $2.8 \mathrm{Al}$ per formula unit. $\mathrm{Fe} / \mathrm{Mg}$ is usually near 1 . Chlorites contain 2.8 to $3.2 \mathrm{Si}, 1.9$ to $2.5 \mathrm{Al}, 1.7$ to $2.6 \mathrm{Fe}$ and 1.3 to 2.4 Mg.

Comparison with porphyry copper systems shows that interlayer chemistry in hydrothermal sericites is related to the alteration assemblage, and chemical heterogeneity is related to alteration intensity or extent of recrystallization of the rock. Analyzed chlorite compositions in porphyry systems are similar to or more magnesian than those at Roosevelt. Sericites from porphyry systems tend to have higher interlayer $(K+N a)$ site occupancies and less Si in tetrahedral sites than those from Roosevelt. Southwest Tintic sericites have nearly constant Fe but variable $\mathrm{Al}$ and $\mathrm{Mg}$ in octahedral sites, Santa Rita sericites have nearly constant $M g$, and Roosevelt sericites nearly constant $\mathrm{Fe} / \mathrm{Mg}$. The differences between systems may be at least partly due to differences in alteration assemblages analyzed. F correlates with Mg content in sericites from all systems.

Sericite and chlorite chemistry is a function, not merely of bulk fluid chemistry and temperature, but also of the local chemical environment, distance from fluid-bearing veins, and the type of mineral being replaced. Thermodynamic modeling shows that the sensitivity of sericite and chlorite chemistry to fluid composition is such that changes in aqueous species activities can cause changes of similar magnitude in the activities of solid 
solution end members. Temperature changes of a few tens of degrees can cause order of magnitude changes in solid phase activities.

Chemical inhomogeneity of alteration minerals, isotopic evidence and thermodynamic modeling indicate a state of disequilibrium between the Roosevelt bulk geothermal fluid and hydrothermal sericite and chlorite. The amount of disequilibrium calculated depends upon the thermodynamic data base used. Alteration minerals may well be in equilibrium with local portions of the present day fluid which have changed composition by reacting with the rock. Sericite solid solution end members and calcite appear to be close to equilibrium with the bulk fluid, feldspars are slightly undersaturated, and chlorite is strongly undersaturated. These data suggest, unless the chlorite thermodynamic data is highly inaccurate, that chlorite may have formed earlier, perhaps during a previous hydrothermal event. 


\author{
HEAT FLOW AND THERMAL HYDROLOGY OF \\ BEOWAWE KGRA, NEVADA \\ Christian Smith \\ November, 1980 \\ Submitted to Geophysics \\ DOE/ID/12079-34
}

\title{
ABSTRACT
}

Forty $150 \mathrm{~m}$ deep thermal gradient holes have been drilled by industry in a $60 \mathrm{~km}^{2}$ area surrounding the Beowawe Geysers as part of the Department of Energy/Division of Geothermal Energy's Northern Nevada Industry Coupled Case Studies Program. Temperature-depth profiles and measurements of thermal conductivity on chip samples from these holes and from Chevron Resource Company's Ginn 1-13 geothermal exploration hole (2917 m T.D.) have been used to produce maps of heat flow and of a shallow thermal aquifer in the Whirlwind valley.

- The anamal ous surface heat loss above the shallow thermal aquifer is estimated to be between 8.6 and $10.4 \mathrm{MW}$, corresponding to a volume flow of water of $0.02-0.03 \mathrm{~m}^{3} \cdot \mathrm{sec}^{-1}$. Thermal gradient and conductivity data from the deep well have a wide range of values $\left(65-144^{\circ} \mathrm{C}^{\circ} \mathrm{km}^{-1} 1.59-5.79 \mathrm{w}^{\circ} \mathrm{m}^{-1} \mathrm{~K}^{-1}\right)$ but produce a relatively constant heat flow of $235 \mathrm{MW}^{*} \mathrm{~m}^{-2}$ above a depth of 1600 m. Near-isothermal conditions in fractured rock below $1600 \mathrm{~m}$ depth indicate the advective transport of heat.

The Dunphy Pass fault zone appears to form the eastern margin of the Beowawe hydrothermal system. If the average heat flow east of the Dunphy Pass fault zone, $110 \mathrm{~mW}^{\circ} \mathrm{m}^{-2}$ is representative of a local 'background' heat flow, the heat loss at Beowawe when The Geysers are dormant exceeds the total flux from a $100-200 \mathrm{~km}^{-2}$ area. Heat lost through the action of The Geysers may increase this estimate by an order of magnitude.

Shal low temperature-depth profiles and open-file data from the U. S. Geological Survey, Water Resources Division, have been used to create water level maps and to compute vertical hydraulic gradients within the Whirlwind Valley. These basic hydrologic data show areas away from The Geysers where thermal water may rise from depth. Additional hydrologic data at the locations of several of the thermal gradient holes may locate viable exploration targets. The systematic acquisition of hydrologic data is recommended as a standard component of hydrothermal resource exploration programs. 


\title{
WELLOG: COMPUTER SOF TWARE SYSTEM FOR
}

ANALYZING AND PLOTTING WELL LOG DATA

(A USER'S GUIDE TO WELLOG. REV2)

\author{
J. W. Atwood \\ T. J. Killpack \\ W. E. Glenn \\ C. Nutter
}

November, 1980

ESL Report

DOE/ID/12079-17 (ESL-45)

\section{ABSTRACT}

WELLOG is a software system that has been developed at the Earth Science Laboratory to plot digitized well log data in a manner suitable for analysis. Multiple logs can be plotted side by side for correlation analysis, and up to three logs can be plotted on a cross plot. Data entry, editing, and modification functions are alos provided by the program.

The WELLOG system is currently operating on the University of Utah Research Institute's PRIME 400 computer. Digitizing is accomplished by a TEKTRONIX 4954 (on-line) digitizing tablet, and plotting is done on a TEKTRONIX 4014 graphics teminal, a STATOS 42 el ectrostatic plotter, or a CALCOMP pen plotter using a device independent plotting system. This program (WELLOG. REV2) is not as system-dependent as the former version (WELLOG REV1). The user must supply a program to digitize the data and supply subroutines to interface the program with file manipulation and plotting routines of their system.

WELLOG. REV2 is greatly improved over WELLOG. REV1. One major improvement is the use of an on line digitizing system whereby the program accesses disk fil es rather than reading the data from tape. In REV 2 the merge file has been automated such that the file is initialized automatically upon creation and al so delete protected. The randomly spaced data capabilities have been greatly improved allowing the averaging and cross plotting of the data. Routines have been added which al low all of the cross plkots excepting the Z-plot to be printed on a line printer. Dresser Atlas" "A-K" plot has also been added. Perhaps most important is the increased portability of WELLOG. REV2. The program is almost completely self contained, needing only a few interfacing and system subroutines.

The WELLOG program may still be of use to those that have no digitizing or plotting capabilities because the program does allow input of data from a user terminal, and can produce line printer plots of most of the cross plots. 


\section{TRACE ELEMENT GEOCHEMISTRY OF GRADIENT HOLE CUTTINGS}

BEOWAWE GEOTHERMAL AREA, NEVADA

Odin D. Christensen

December, 1980

ESL Report

$D O E / 10 / 12079-21$ (ESL-48)

\section{ABSTRACT}

Multielement geochemical analysis of drill cuttings from 26 shallow temperature-gradient drill holes and of surface rock samples reveals trace element distributions developed within these rocks as a consequence of chemical interaction with thermal fluid within the Beowawe geothrmal area. The presently discharging thermal fluids are dilute in all components except silica, suggesting that the residence time of these fluids within the thermal reservoir has been short and that chemical interaction with the reservoir rock minimal. Interaction between these dilute fluids and rocks within the system has resultied in the development of weak chemical signatures. The absence of stronger signatures in rocks associated with the present system suggests that fluids have had a similar dilute chemistry for some time. The spatial distribution of elements commonly associated with geothermal systems, such as $\mathrm{As}, \mathrm{Hg}$ and $\mathrm{Li}$, are neither laterally nor vertically continuous. This suggests that there is not now, nor has there been in the past, pervasive movement of thermal fluid throughout the sampled rock but, instead, that isolated chemical anomalies represent distinct fluid-flow channetls. Coherent near-surface enrichments of As and Mn are consistent with a system in which fluids discharge from along the Malpais Fault and flow downslope within shall ow permeable horizons, depositing As near the discharge point and Mn more distally. Discontinuous $\mathrm{As}, \mathrm{Li}$ and $\mathrm{Hg}$ concentrations near White Canyon to the east of the presently active surface features record the effects of chemical interaction of rocks with fluids chemically unlike the presently discharging fluids. The observed trace element distributions suggest that historically the Beowawe area has been the center of more than one hydrothermal event and that the near-surface portion of the present hot-water geothermal system is controlled by a single source fracture, the Malpais Fault, or an interseciton of faults at the sinter terrace. 


\title{
GEOCHEMISTRY OF SELECTED ROCK SAMPLES \\ COLADO GEOTHERMAL AREA, NEVADA
}

\author{
by \\ Odin D. Christensen \\ Bruce S. Sibbett \\ Michael J. Bullett \\ January 1981
}

ESL Report

DOE/ID/12079-24 (ESL-50)

\begin{abstract}
This report presents the results of the chemical analysis of 30 surface rock samples from the Colado geothermal area. The samples represent a variety of materials affected by several hydrothermal events which have formed $\mathrm{Au}$, $\mathrm{Sb}$ and clay deposits within the area. The active geothermal system is currently being evaluated for electrical power production.

The elements $\mathrm{As}, \mathrm{Sb}, \mathrm{Au}, \mathrm{Ag}, \mathrm{Li}$ and $\mathrm{Hg}$ have been concentrated during more than one of the hydrothermal events which have affected the Colado area. Distinct chemical signatures do not exist for any particular event, instead, it appears that this suite of elements has been repeatedly remobilized, probably in response to similar physical and chemical conditions and processes. Delineation of geochemical zoning related to the active geothermal system is possible only because it is spatially separated from the older hydrothermal deposits.

The chemical similarity between the older hydrothermal events and the present hydrothermal system suggest that the $\mathrm{Sb}$ and $\mathrm{Au}$ mineralization formed at shal low depths in a boiling geothemal environment. It is suggested that new ore zones may be discovered in the willard mining district if the geothermal model is applied to exploration.
\end{abstract}




\section{IPINV: A Two-Dimensional Dipole-Dipole Resistivity Modeling and Inversion Program \\ (User's Guide and Documentation for Rev. 1)}

Alan C. Tripp

Terry J. Killpack

January, 1981

ESL Report

DOE/ID/12079-25 (ESL-51)

\section{INTRODUCTION}

IPIN. REVI is a batch program that is capable of inverting resistivity data to two-dimensional models for a dipole-dipole array. The forward problem is computed using a transmission surface analogy.

Resistivity data are frequently gathered over conductivity structures which are approximately two-dimensional. Several computer algorithms that compute the forward response of two dimensional structures have been developed and used in routine data interpretation (Madden, 1971; Rijo, 1977; Dey and Morrison, 1976). An interpreter using these forward algorithms can have difficulties in determining the size and direction of the parameter perturbations necessary for convergence of the trial-and-error forward modeling. Pelton et al., (1978) optimized the step-size in parameter space for a single two-dimensional body in a host rock by utilizing the technique of 1 inearized least-squares. The partial derivatives necessary for the least squares inversion were calculated by referencing a forward response data file and interpolating between models. This method provides cheap, accurate interpretations of a given simple model type but breaks down if the interpretation requires a complicated model.

IPINV. REV1 is capable of inverting resistivity data to two-dimensional models of arbitrary complexity. The program was written by Alan C. Tripp while a graduate student in the Department of Geology and Geophysics at the University of Utah. The details of the theory and methodology of the program are given in Tripp et al., (in prep). The two-dimensional forward modeling routine is based on the transmission surface analogy (Madden, 1972). The inversion algorithm is a linearized least-squares technique. Step-size stabilization is provided by either the Box-Kanemaesu (1972) method or by using a Marquardt step. The program uses log derivatives to increase the rate of convergence. 


\author{
EXPLORATION CASE HISTORY OF THE MONROE KGRA, \\ SEVIER COUNTY, UTAH \\ Jeffrey B. Hulen \\ Susan M. Sandberg \\ March, 1981 \\ ESL Report \\ DOE/ID/12079-22 (ESL-49)
}

\title{
ABSTRACT
}

The University of Utah Department of Geology and Geophysics (UU/GG) and TerraTek Inc., of Salt Lake City completed an integrated multi-discipline geoscientific evaluation of the Monroe KGRA, in south-central Utah, between 1975 and 1978. This study was designed not only to characterize and devel op the Monroe geothermal resource, but also to assess the value of various techniques in exploration for low- to moderate-temperature geothermal systems elsewhere. Methods applied at Monroe comprised: large scale $(1: 18,900)$ mapping of geology, springs and spring deposits, and alteration; statistical analysis of the alteration; spring geochemistry and geothemometry; gravity; ground magnetics; dipole-dipole resistivity surveying; shallow thermal gradient drilling; test well drilling; and finally production well drilling.

The Monroe KGRA is centered on the village of Monroe, at the eastern boundary of Sevier Valley, a deeply alluviated. Basin and Range graben in south-central Utah. The valley is separated from the Sevier Plateau, to the east, by the Sevier fault zone, a structure with up to $1800 \mathrm{~m}$ ( $5905.6 \mathrm{ft}$ ) nomal displacement. The plateau, including that poriton eccompassed by the KGRA, is constructed of mostly intermediate-composition volcanics of 01 igocene to P1iocene age. Several "hot" (61-76.3 $\left.{ }^{\circ} \mathrm{C} / 141.8-169.4^{\circ} \mathrm{F}\right)$ springs and associated travertine deposits are aligned along the Sevier fault zone within the KGRA. Alluvium around these deposits, as well as landslide debris and volcanic bedrock, are argillized and propylitically altered in scattered patches along faults and fractures.

Large-scale $(1: 18,900)$ mapping at Monroe primarily demonstrated control by the Sevier fault zone and allied structures of the springs, spring deposits and alteration. Most of the alteration was shown to be very young and probably related to present geothermal activity because of its development in faults disrupting surficial deposits.

Reservoir temperatures estimated by geothermometry of the sodiumchloride-sulfide spring waters at Monroe varied from $60^{\circ} \mathrm{C}\left(140^{\circ} \mathrm{F}\right)$ (alpha cristobalite) to $179^{\circ} \mathrm{C}\left(354^{\circ} \mathrm{F}\right)(\mathrm{Na}-\mathrm{K}-1 / 3 \mathrm{Ca})$. Actual maximum temperature encountered by the deepest drilling at Monroe $\left(82.2^{\circ} \mathrm{C} / 180^{\circ} \mathrm{F}\right)$ was closely approximated by the chalcedony geothermometer $\left(81^{\circ} \mathrm{C} / 178^{\circ} \mathrm{C}\right)$.

Detailed gravity and ground magnetic studies confirmed the presence of the Sevier fault zone and indicated it to consist of echelon segments rather than a single structure. 
Dipole-dipole resistivity surveying delineated an elongate resistivity low tightly controlled by the Sevier fault zone, centered beneath these mounds to depth of at least $400 \mathrm{~m}(1312.4 \mathrm{ft})$. A zone of shal low thermal fluid leakage in permeable alluvium was also detected.

Shallow ( $<100 \mathrm{~m} / 328 \mathrm{ft}$ ) thermal gradient/heat flow drilling at Monroe showed highest heat flow values, up to $81 \mathrm{HFU}\left(3400 \mathrm{~mW} / \mathrm{m}^{2}\right)$, approximately coinciding with the travertine mounds. An empirically derived relationship between heat flow and resistivity allowed extrapolation of heat flow contours beyond actual drill hole control.

Results of the geological and geophysical investigation strongly suggested direct-heating potential for the Monroe resource. Accordingly, two shal low $(110.3 \mathrm{~m} / 362 \mathrm{ft}$ amd $251 / 6 \mathrm{~m} / 825.5 \mathrm{ft})$ test wells were drilled to define better the subsurface thermal and structural regimes and quide placement of a production wel1. Both wells produced strong artesian flows at about $74^{\circ} \mathrm{C}\left(165^{\circ} \mathrm{F}\right)$ from the Sevier fault zone, which separates alluvium from subjacent latite bedrock.

These encouraging results led to completion of a production well. The well intersected alluvium, a thick, unanticipated limestone sequence, then (as predicted) the Sevier fault zone, with artesian themal fluid flow, between about 320 and $350.5 \mathrm{~m}$ ( 1050 and $1150 \mathrm{ft}$ ). The well then entered latite bedrock, in which it rema ined to its total depth of $457.2 \mathrm{~m}$ (1500 ft).

After development, the production well produced an artesian flow of 280 gpm at a temperature of $73.3^{\circ} \mathrm{C}\left(164^{\circ} \mathrm{F}\right)$. Pump tests at $330 \mathrm{gpm}$ for 70 hours and $600 \mathrm{gpm}$ for 30 hours produced drawdowns internally and in test wells of up to $76 \mathrm{~m}(250 \mathrm{ft})$. All springs near the production well dried up during pump testing.

Analys is of the pump test results indicated that unacceptably large drawdowns would occur during projected peak winter heating periods for Monroe. This discouraging forecast, the rather low reservoir temperatures encountered in the production well, and inflationary factors rendering geothermal energy at Monroe uncompetitive with coal as a heat source, led to concellation of plans to further develop the resource. The UU/GG-TerraTek exploration program at Monroe nonetheless remains an impressive technical success. 
LITHOLOGY AND WELL LOG STUDY OF CAMPBELL "E-2", GEOTHERMAL TEST WELL, HUMBOLDT HOUSE GEOTHERMAL PROSPECT

PERSHING COUNTY, NEVADA

Bruce S. Sibbett

W. E. Glenn

August, 1981

ESL Report

DOE/ID/12079-27 (ESL-53)

\section{ABSTRACT}

In 1979 Phillips Petroleum Company completed the Campbell E-2 geothermal test well to a depth of 8060 feet $(2456.7 \mathrm{~m})$ in Section 15, T31N, R33E, to evaluate the geothermal potential of the Humboldt House thermal area on the northwest side of the Humboldt Range, Pershing County, Nevada. The cuttings and well logs were made available for study by the Earth Science Laboratory, University of Utah Research Institute through the DOE/DGE Industry Coupled Program. The well location is shown on figure 1.

The thermal area is located on the west side of the Humboldt Range (Figure 1), in the Basin and Range physiographic province. The valley fill consists of Quaternary to Tertiary all uvium (Johnson, 1977), lake sediments and volcanic rocks. East of the range front fault, Triassic slates of the Grass Valley Formation and Natchez Pass Formation are thrust over the Triassic Prida Fomation and older rocks (Figure 2). The geology of the range was mapped by Silberling and Wallace (1967).

No active hot springs are known in the area, but siliceous and calcareous sinter deposits are exposed in the valley about three miles northwest of the Campbel1 E-2 well (Garside and Schilling, 1979, p. 61). A 600-foot-thick interval of siliceous sinter was encountered bel ow 700 feet of alluvium in the Campbell E-1 hole (Earth Science Lab., 1979). 
LIGHT STABLE ISOTOPE STUDIES OF SPRING AND THERMAL WATERS FROM THE ROOSEVELT HOT SPRINGS AND COVE FORT/SULPHURDALE THERMAL AREAS AND

OF CLAY MINERALS FROM THE ROOSEVELT HOT SPRINGS THERMAL AREA

\author{
John R. Bowman \\ David T. Rohrs \\ October, 1981 \\ UUGG Report
}

DOE/ID/12079-44

\begin{abstract}
The isotopic compositions of hydrogen and oxygen have been determined for spring waters and themal fluids from the Roosevelt Hot Springs and Cove FortSulphurdale themal areas, for clay mineral separates from shallow alteration of the acid-sulfate type in the Roosevelt Hot Springs area, and for spring and well waters from the Goshen Valley area of central Utah. The water analyses in the Roosevelt Hot Springs thermal area confirm the origin of the thermal fluids from meteoric water in the Mineral Range. The water analyses in the Cove Fort-Sulphurdale themal area restrict recharge areas for this sytem to the upper el evations of the Pavant and/or Tushar Ranges. The low 180 shift observed in these thermal fluids $(+0.7$ permil) implies either high water/rock ratios or incomplete isotope exchange or both, and further suggests minimal interaction between the thermal fluid and marble country rock in the system. Hydrogen and oxygen-isotope data for clay mineral separates from shallow alteration zones in the Roosevelt Hot Springs thermal system suggest that the fluids responsible for the shal low acid-sulfate alteration were in part derived from condensed steam produced by boiling of the deep reservoir fluid. The isotope evidence supports the chemical model proposed by Parry et a1. (1980) for origin of the acid-sulfate alteration at Roosevelt Hot Springs. The isotope analyses of spring and well waters from the Goshen Valley area indicate only a general correlationof isotope composition, salinity and chemical temperatures.
\end{abstract}


LATE CENOZOIC VOLCANISM AT TWIN PEAKS, UTAH:

\author{
GEOLOGY AND PETROLOGY \\ H. R. Crecraft \\ W. P. Nash \\ S. H. Evans, Jr. \\ November, 1981 \\ UUGG Report
}

DOE/ID/12079-55

\title{
ABSTRACT
}

Bimodal volcanism that formed in the Twin Peaks volcanic complex, westcentral Utah, spanned a period from 2.7 to $<1 \mathrm{m.y}$. , and produced approximately $12 \mathrm{~km}^{3}$ of erupted material. Two sequences of differentiation can be discerned in the silicic lavas; both are characterized by increases in $\mathrm{SiO}_{2}$ from $71 \%$ to $76 \%$ and decreases in temperature from $875^{\circ} \mathrm{C}$ to $775^{\circ} \mathrm{C}$. The first sequence erupted from 2.7 to $2.5 \mathrm{~m} . y$. , produced $>10 \mathrm{~km}^{3}$ of aphyric lavas and pyroclastic deposits and resulted in a local subsidence of approximately 100 $\mathrm{m}$. Tuffaceous lake deposits followed by voluminous olivine tholei ites subsequently filled the depression. Eruption of the second sequence of siliciç rocks spanned a short time at $2.4 \mathrm{~m} . \mathrm{y}$. and produced a total volume of $0.7 \mathrm{~km}^{3}$ of strongly porphyritic felsites. At least two subsequent episodes of basaltic volcanism followed. Chemical variations displayed by the early differentiation sequence of silicic rocks are characterized by increases in volatiles, $\mathrm{SiO}_{2}, \mathrm{Na}_{2} \mathrm{O}$, heavy rare-earths, $\mathrm{Rb}$, and highly charged cations and decreases in afi other major components, 1 ight rare-earths, Sr, and $\mathrm{Ba}$. These variations in time closely resemble spatial variations in compositionally zoned ash flow sheets and are incompatible with crystal fractionation. The early differentiation sequence resulted in the development of a highly evolved, compositional ly stratified roof zone, from which the ash and aphyric lavas were tapped. Conductive cooling models for the silicic magma chamber require thermal input into the system, probably by underplating a large volume of basalt, during the early eruptive sequence to sustain it beyond 50,000 years after initial emplacement. Chemical variations displayed by the second eruptive sequence exhibit an increase in $K$ and decrease in $\mathrm{Na}$ and are consistent with crystal fractionation as the dominant control. Crystal fractionation and a short eruptive history indicate rapid cooling and a cessation of thermal input for the second sequence. 
TWO-DIMENSIONAL MODELING RESULTS OF TELLURIC-MAGNETOTELLURIC DATE

FROM THE TUSCARORA AREA, ELKO COUNTY, NEVADA

Claron E. Mackelprang

January, 1982

ESL Report

DOE/ID/12079-48 (ESL-63)

\section{ABSTRACT}

Two-dimensional modeling of T-MT data taken at the Tuscarora Geothermal Exploration unit has shown that in this area the TM-Mode is insensitive in resolving conductivity inhomogeneities below a depth of about $2 \mathrm{~km}$. Computer interpretive models showing a large conductive zone beneath the hot spring area at a depth of $2 \mathrm{~km}$ are compared with models in which this conductive zone is restricted to the near surface. Acceptable fits betwen observed apparent resistivity and calculated resistivity, within the accuracy of the field data, have also been obtained with alternate models. This non-uniqueness is inherent in the two-dimensional models thenselves and is further complicated by the geologic setting where three-dimensional effects result from nearsurface conduct ive bodies. Current channeling within the conductive sediments of Independence Valley many also 1 imit the ability to resolve postulated, deep conduct ivity inhomogeneities.

Any interpretation of T-MT data, possibly leading to a deep exploration drill test, sould be evaluated through a sensititivity analysis (i.e., several alternate models). Three-dimensional effects should also be evaluated to the extent possible. Finally, supporting evidence derived from al ternate exploration techniques should be integrated with T-MT interpretive conclusions. 


\section{LITHOLOGIC INTERPRETATION OF THE DE BRAGA \#2 AND RICHARD WEISHAUPT \#1}

GEOTHERMAL WELLS, STILLWATER PROJECT, CHURCHILL COUNTY, NEVADA

Bruce S. Sibbett

Robert E. Blackett

February 1982

ESL Report

DOE/ID/12079-57 (ESL-70)

\section{ABSTRACT}

The De Braga \#2 and Richard Weishaupt \#1 geothermal test wells were drilled by Union $0 i 1$ Company, Geothermal Division, between 1979 and 1981 as part of the U.S. Department of Energy, Divison of Geothermal Energy, Industry Coupled Program.

They are in the Stillwater area, located on the southeast side of the Carson Desert in Churchill County, Nevada (Figure 1). Hot water was first discovered in the area in 1919 (Garside and Schilling, 1979). There are no known surface manifestations of geothermal activity in the immediate vicinity, however, basaltic cinder cones at Soda Lake, a few miles to the west, are the result of phreatic explosions during the Quaternary (Sibbett, 1979). 


\title{
INTERPRETATION OF THE DIPOLE-DIPOLE ELECTRICAL RESISTIVITY SURVEY, TUSCARORA GEOTHERMAL AREA, ELKO COUNTY, NEVADA

\author{
Claron E. Mackelprang
}

February 1982

ESL Report

DOE/10/12079-59 (ESL-72)

\begin{abstract}
Interpretation of Tuscarora geothermal area model results has suggested that low-resistivity zones on two dipole-dipole lines (9 and 16) and possibly on a third (line 5) are related to themal fluids. The two-dimensional models have delineated what appear to be aquifers within the valley sediments and the Tertiary volcanics. Structural breaks noted at the surface by geologic mapping are also evident in the interpretive models.

The area southeast of the hot springs in Hot Creek is poorly del ineated by the current dipole-dipole coverage, yet this appears to be the most pramising prospect area based upon the available data coverage. Exploratory drilling is currently moving in this direction. Perhaps additional dipoledipole lines could aid in the selection of future drill sites.
\end{abstract}


GEOPHYSICAL INVESTIGATIONS OF THE BALTAZOR HOT SPRINGS KNOWN GEOTHERMAL RESOURCE AREA AND THE PAINTED HILLS THERMAL AREA, HUMBOLDT COUNTY, NEVADA

Ronald K. Edquist

February 1982

ESL Report

DOE/ID/12079-29 (ESL-54)

ABSTRACT

This report describes geophysical investigations of the Baltazor Hot Springs KGRA and the Painted Hills thermal area, Humboldt Co., Nevada. The study includes a gravity survey of 284 stations covering $750 \mathrm{sq} \mathrm{km}$, numerical modeling and interpretation of five detailed gravity profiles, numerical modeling and interpretation of 21.8 line-km of dipole-dipole electrical resistivity data along four profiles, and a qualitative interpretation of 38 line-km of self-potential data along eight profiles. The primary purpose of the investigation is to try to determine the nature of the geologic controls of the themal anomalies at the two areas.

At Baltazor KGRA, the control is interpreted to be a narrow, northtrending Basin and Range structure which has as much as $610 \mathrm{~m}$ of alluvial fill in a narrow graben. The faulting associated with this Basin and Range structure is interpreted as tapping aquifers in the Steens Basalt which contain thermal fluids at elevated temperatures. The main thermal activity at Baltazor KGRA is localized al ong the west side of Continental Lake Valley by a north-trending, range-bounding fault zone. This fault zone has expression in the gravity and resistivity data, as well as being coincident with an approximately $100 \mathrm{mv}$ self-potential anomaly.

The primary geologic features at the Painted Hills area are, 1) a thick sequence (up to $760 \mathrm{~m}$ ) of low density, low resistivity, tuffaceous rocks (Thousand Creek Formation) bordering the Rock Spring Table on the east, and 2) a high density zone marginal to the Table which is interpreted as an area of intense alteration or possibly rhyolitic intrusive. The data are insufficient to determine a likely cause of the thermal anomaly here, but one good possibility is that the thermal gradient is related to the intensity of alteration. The physiography of the Painted Hills area is more typical of the plateau regions to the west and north rather than of the Basin and Range Province. This change of physicography within the study area is apparent in the gravity maps.

The gravity data cover a sufficient area such that features of a more regional scale have expression in gravity maps encompassing both Baltazor KGRA and the Painted Hil ls thermal area. A $30 \mathrm{mgal}$ gravity low in Thousand Creek valley is modeled in cross section as up to $3 \mathrm{~km}$ of post-Miocene tuffaceous valcanic and sedimentary basin fill. This fill overlies Steens Basalt which dips approximately $10^{\circ}$ to the southwest from the surface exposure in the 
Pueblo Mountains. From the cross section modeling, Bog Hot Springs, like Baltazor Hot Springs, appears to be controlled by the location of recent faults which tap aquifers in the steens Basalt. A low in the gravity data that extends northeast from the Painted Hills area through the narrow playa val ley containing Baltazor Hot Springs is interpreted as the extension of a prominent topographic linear that begins $104 \mathrm{~km}$ to the southwest at the Soldier Meadow Hot Springs. This suggests that the thermal anomalies at these areas may be generically related and that this linear may be a good geothermal exploration target.

Similarly, the Eugene-Denio fault zone, a proposed belt of transform faulting marginal to the Basin and Range province, projects through the northeastern portion of the study area. The fault zone appears to have expression in the gravity data and it has been noted in previous geologic work. The fault zone appears to be important at Baltazor Hot Springs and hence it may be an important exploration guide el sewhere.

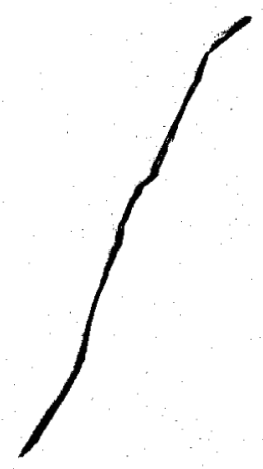


INTERPRETATION OF GEOPHYSICAL DATA FROM THE

COLADO KGRA, PERSHING COUNTY, NEVADA

Claron E. Mackelprang

Apri1 1982

ESL Report

DOE/ID/12079-58 (ESL-71)

\section{ABSTRACT}

The Colado geothermal area is evidenced by hot water wells in alluvium along the west flank of the west Humboldt Range. The exploration of this geothemal system has progressed into advanced stages with completion of shallow thermal gradient drilling, two intermediate-depth exploration drill holes, one deep exploration drill hole, detailed geologic mapping, dipoledipole resistivity gravity, ground magnetics, MT-AMT, TDEM and assorted uncommon el ectrical resistivity techniques.

A thermal anomaly was outlined by the shallow drilling. Dipole-dipole resistivity and gravity data along with detailed geologic mapping have suggested that this anomaly is structurally controlled. Other geophysical techniques employed do not appear to contribute to an understanding of the geothermal anomaly. The two intermediate-depth exploration holes (IGH-1, IGH2) and the one deep hole $(44 \times 10)$ may not have been located in the most favorable portions of the geothermal anomaly. The area having the greatest exploration potential for intermediate-depth drilling appears to be centered on the shallow drill hole 14-22. An intermediate-depth drill hole located near DH14-22 is most likely to encounter one of the conduits that allow thermal waters to rise near the surface. 
REVIEW OF WELL LOGGING IN THE BASIN AND RANGE KNOWN

GEOTHERMAL RESOURCE AREAS

\author{
W. E. Glenn \\ H. P. Ross \\ J. W. Atwood \\ May 1982 \\ Journal Article \\ Journal of Petroleum Technology
}

\begin{abstract}
This paper discusses applications and interpretaitons of well logs to Basin and Range Province geothermal exploration and development. Problems experienced in use of conventional oilfield tools and techniques are reviewed, and methods of circumventing these problems are illustrated. Particular examples focus on $\log$ responses and matrix effects in complex lithologies.
\end{abstract}


A STUDY OF WELL LOGS FROM COVE FORT-SULPHURDALE KGRA, MILLARD AND BEAVER COUNTIES, UTAH

\author{
W. E. Glenn \\ H. P. Ross \\ JuTy 1982 \\ ESL Report \\ DOE/ID/12079-62 (ESL-75)
}

\begin{abstract}
Union Oil Company drilled four geothermal test wells in the Cove FortSulphurdale KGRA between 1975 and 1979. A fairly complete suite of well logs were recorded for the three deeper holes, and these data are presented as composite well log plots in this report. The composite well log plots have facilitated the interpretation of limestone, dolomite, sandstone, quartzmonzonite, serpentine, and volcanic lithologies and the identification of numerous fractures. This has been especially helpful because of the extensive lost circulation zones and poor cuttings recovery. Intraformational flow was identified by a fluid migration-temperature tracer log at depth in CFSU 31-33.

Well $10 \mathrm{~g}$ cross plots were computed to assist in lithologic identification and the determination of physical properties for specific depth intervals in a given hole. The presence of hydrous minerals sometimes results in neutron porosity somewhat higher than the true nonfracture porosity, which is generally less than $4 \%$. Permeability is clearly controlled by fractures. A maximum well temperature of $178.9^{\circ} \mathrm{C}$, low flow rates and low probable percent flash indicate these wells are subeconomic for electric generation at present. The well $l$ og study has substanitally improved our understanding of the reservoir as presently drilled.
\end{abstract}


GEOTHERMAL MINERAL IZATION I: THE MECHANISM OF FORMATION

OF THE BEOWAWE, NEVADA SILICEOUS SINTER DEPOSIT

J. D. Rimstidt
David R. Cole

Journal Article

American Journal of Science

\section{ABSTRACT}

The siliceous sinter deposit at Beowawe, Nevada has a volume of $7.7 \times 10^{7}$ $\mathrm{m}^{3}$ and contains $1.28 \times 10^{\mathrm{Il}} \mathrm{kg}$ silica. This silica precipitated from geothemal solutions that welled-up al ong the Malpais Fault, a graben bounding fault. Sinter formation involved three steps: (1) Geothermal solutions that were saturated with quartz in the reservoir moved to the surface where they cooled and became supersaturated with amorphous silica. (2) Amorphous silica particles nucleated (heterogeneously on ferric hydroxides) to produce a colloidal suspension. (3) The amorphous silica particles agglomerated and were cemented together by amorphous silica precipitating in the embayments between the particles. At least $5.58 \times 10^{14} \mathrm{~kg}$ of geothermal solution must have been produced over time to account for the mass of silica in the Beowawe deposit. This fluid would have carried at least $4.95 \times 10^{17} \mathrm{~kJ}$ of heat to the surface. 


\author{
FLUID-MINERAL EQUILIBRIA IN A HYDROTHERMAL SYSTEM, \\ ROOSEVELT HOT SPRINGS, UTAH \\ Regina M. Capuano \\ David R. Cole \\ March 30,1982 \\ Journal Article \\ Geochimica et Cosmochimica Acta
}

\begin{abstract}
The availability of fluids and drill cuttings from the active hydrothermal system at Roosevelt Hot Springs allows a quantitative comparison between the observed and predicted alteration mineralogy, calculated from fluid-mineral equilibria relationships. Comparison of all wells and springs in the thermal area indicates a common reservoir source, and geothermometer calculations predict its temperature to be higher $\left(288^{\circ} \mathrm{C} \pm 10^{\circ}\right)$ than the maximum measured temperature of $268^{\circ} \mathrm{C}$.

The composition of the deep reservoir fluid was estimated from surface well samples, allowing for steam loss, gas release, mineral precipitation and ground-water mixing in the well bore. This deep fluid is sodium chloride in character, with approximately $9700 \mathrm{ppm}$ dissolved $\$ 9 l i d s, 2 \mathrm{pH}$ of 6.0 , and gas partial pressures of $\mathrm{O}_{2}$ ranging from $10^{-32}$ to $10^{-35} \mathrm{~atm}, \mathrm{CO}_{2}$ of $11 \mathrm{~atm}, \mathrm{H}_{2} \mathrm{~S}$ of $0.020 \mathrm{~atm}$ and $\mathrm{CH}_{4}$ of $0.001 \mathrm{~atm}$.

Comparison of the alteration mineralogy from producing and nonproducing wells allowed delineation of an alteration pattern characteristic of the reservoir rock. Theoretical alteration mineral assemblages in equilibrium with the deep reservoir fluid, between $150^{\circ}$ and $300^{\circ} \mathrm{C}$, in the system $\mathrm{Na}_{2} \mathrm{O}-\mathrm{K}_{2} \mathrm{O}-$ $\mathrm{CaO}-\mathrm{MgO}-\mathrm{FeO}-\mathrm{Fe}_{2} \mathrm{O}_{3}-\mathrm{Al}_{2} \mathrm{O}_{3}-\mathrm{H}_{4} \mathrm{SiO}_{4}-\mathrm{H}_{2} \mathrm{O}-\mathrm{H}_{2} \mathrm{~S}-\mathrm{CO}_{2}-\mathrm{HCl}$, were cal cualted. Minerals theoretically in equilibrium with the calculated reservoir fluid at $>240^{\circ} \mathrm{C}$ include sericite, $K-f e l d s p a r$, quartz, chal cedony, hematite, magnetite and pyrite. This assemblage corresponds with observed higher-temperature $\left(>210^{\circ} \mathrm{C}\right)$ alteration assemblage in the deeper parts of the producing wells. The presence of montmorillonite and mixed-layer clays with the above assemblage observed at temperatures $\left\langle 210^{\circ} \mathrm{C}\right.$ corresponds with minerals predicted to be in equilibrium with the fluid below $240^{\circ} \mathrm{C}$.
\end{abstract}

Alteration minerals present in the reservoir rock that do not exhibit equilibrium with respect to the reservoir fluid include epidote, anhydrite, calcite and chlorite. These may be products of an earlier hydrothermal event, or processes such as boiling and mixing, or a result of errors in the equilibrium calculations as a result of inadequate themochemical data. 
ROOSEVELT HOT SPRINGS GEOTHERMAL SYSTEM, UTAH - CASE STUDY

\author{
H. P. Ross \\ D. L. Nielson \\ J. N. Moore \\ July 1982 \\ Journal Article \\ American Association of Petroleum Geologists Bulletin
}

\title{
ABSTRACT
}

The Roosevelt Hot Springs geothermal system has been undergoing intensive exploration since 1974 and has been used as a natural laboratory for the development and testing of geothermal exploration methods by research organizations. This paper summarizes the geological, geophysical, and geochemical data which have been collected since 1974, and presents a retrospective strategy describing the most effective means of exploration for. the Roosevelt Hot Springs hydrothermal resource.

The bedrock geology of the area is dominated by metamorphic rocks of Precambrian age and felsic plutonic phases of the Tertiary Mineral Mountains intrusive complex. Rhyolite flows, domes and pyroclastic rocks reflect igneous activity between 0.8 and $0.8 \mathrm{m.y}$. ago. The structural setting includes older low-angle nomal faulting and east-west faulting produced by deep-seated regional zones of weakness. North-to northeast-trending faults are the youngest structures in the area, and they control present fumarolic activity. The geothermal reservoir is controlled by intersections of the principal zones of faulting.

The geothermal fluids that discharge from the deep wells are dilute sodium chloride brines containing approximately 7,000 ppm total dissolved solids and anomal ous concentrations of $F, A s, L i, B$, and $\mathrm{Hg}$. Geothemometers calculated from the prdicted cation contents of the deep reservoir brine range from 520 to $531^{\circ} \mathrm{F}\left(271\right.$ to $\left.277^{\circ} \mathrm{C}\right)$. Hydrothermal alteration by these fluids has produced assemblages of clays, alunite, muscovite, chlorite, pyrite, calcite, quartz, and hematite. Geochemical analyses of rocks and soils of the Roosevelt Hot Springs themal area demonstrate that $\mathrm{Hg}, \mathrm{As}, \mathrm{Mn}, \mathrm{Cu}, \mathrm{Sb}, \mathrm{W}, \mathrm{Li}$, $\mathrm{Pb}, \mathrm{Zn}, \mathrm{Ba}$, and $\mathrm{Be}$ have been transported and redeposited by thermal fluids.

The geothermal system is well expressed in electrical resistivity and thermal-gradient data and these methods, coupled with geologic mapping, are adequate to delineate the fluids and alteration associated with the geothermal reservoir. The dipole-dipole array seems best suited to acquire and interpret the resistivity data, although controlled source AMT (CSAMT) may be competitive for near-surface mapping. Representations of the thermal data as temperature gradients, heat flow, and temperature are all useful in exploration of the geothermal system, because the thermal fluids themselves rise close to the surface. Self-potential, gravity, magnetic, seismic, and magnetotelluric survey data all contribute to our understanding of the system, but are not considered essential to its exploration. 
THE COVE FORT-SULPHURDALE KGRA

A GEOLOGIC AND GEOPHYSICAL CASE STUDY

\author{
H. P. Ross \\ J. N. Moore \\ 0. D. Christensen
}

September 1982

ESL Report

DOE/ID/12079-64 (ESL-90)

\begin{abstract}
Geological, geochemical and geophysical data are presented for one of the major geothermal systems in the western United States. Regional data indicate major tectonic structures which are still active and provide the conduits for the geothermal system. Detailed geologic mapping has defined major glide blocks of Tertiary volcanics which moved down fran the Tushar Mountains and locally act as a leaky cap to portions of the presently known geothermal system. Mapping and geochemical studies indicate three periods of mineralization have affected the area, two of which are unrelated to the present geothermal activity. The geologic relationships demonstrate that the major structures have been opened repeatedly since the Tertiary.

Gravity and magnetic data are useful in defining major structures beneth alluvium and basalt cover, and indicate the importance of the Cove Fort-Beaver graben and Cove Creek fault in localizing the geothermal reservoir. These structures and a high level of microearthquake activity also suggest other target areas within the larger thermal anomaly. Electrical resistivity surveys and thermal gradient holes both contribute to the delineation of the known reservoir.

Deep exploration wells which test the reservoir recorded maximum temperatures of $178^{\circ} \mathrm{C}$ and almost isothermal behavior beginning at 700 to 1000 $\mathrm{m}$ and continuing to a depth of $1800 \mathrm{~m}$. Costly drilling, high corrosion rates and low reservoir pressure coupled with the relatively low reservoir temperatures have led to the conclusion that the reservoir is not economic for electric power production at present. Plans are underway to utilize the moderate-temperature fluids for agribusiness, and exploration continues for a deep high-temperature reservoir.
\end{abstract}




\section{MULTIELEMENT GEOCHEMISTRY OF THREE GEOTHERMAL WELLS \\ COVE FORT-SULPHURDALE GEOTHERMAL AREA, UTAH \\ Odin D. Christensen}

September 1982

ESL Report

DOE/ID/12079-80 (ESL-101)

\section{ABSTRACT}

Mult ielement geochemical analys is of drill cuttings from three geothermal wells, Utah State 42-7, Utah State 31-33 and Forminco \#1, in the Cove FortSulphurdale KGRA, Utah, demonstrates that the distributions of different elements are the result of different chemical processes operating throughout the geologic history of the area. Statistical analys is of geochemical data distributions confirm the presence of several distinct element associations.

Of the 36 el ements determi ned on the samples, 12 (V, Mo, $\mathrm{Cd}, \mathrm{Ag}, \mathrm{Au}, \mathrm{Sb}$, $\mathrm{Bi}, \mathrm{U}, \mathrm{Te}, \mathrm{Sn}, \mathrm{B}$ and $\mathrm{Th})$ were present in concentrations at or bel ow detection levels. Of the remaining 24 elements, only 3 ( $\mathrm{Ni}, \mathrm{Co}_{\mathrm{O}}$ and $\mathrm{Zr}$ ) are lognomally distributed. Distributions for the remaining elements are of aggregate populations which represent background, mineralization or other processes.

\section{Pearson correlation coefficients reveal four elemental groupings:}

1) $\mathrm{Na}-\mathrm{K}-\mathrm{Fe}-\mathrm{Al}-\mathrm{Ti}-\mathrm{P}-\mathrm{Sr}-\mathrm{Ba}-\mathrm{Cr}-\mathrm{Ni}-\mathrm{Li}-\mathrm{Be}-\mathrm{Zr}-\mathrm{La}-\mathrm{Ce}$

2) $\mathrm{Ca}-\mathrm{Mg}$

3) $\mathrm{Mn}-\mathrm{Co}-\mathrm{Pb}-\mathrm{Zn}-\mathrm{As}-\mathrm{Hg}$

4) $\mathrm{Cu}$

Groups 1 and 2 are related to the 1 ithogeochemistry of the host rocks, the first association representing intervals of volcanic and clastic lithologies and the second association representing carbonates. The third group represents elements associated with hydrothermal enrichment. Cu alone does not correlate significantly with any other element. Lithogeochemistry is the most significant chemical control both in terms of the number of elements and in terms of the magnitude of the resultant variations.

In the Cove Fort-Sulphurdale system, only the distribution of $\mathrm{Hg}$ can be related to the location of the present geothermal system. Enrichments in other elements, particularly As, $\mathrm{Pb}, \mathrm{Zn}, \mathrm{Mn}$ and $\mathrm{Cu}$ are primarily related to older mineralizing events. Frequent spatial coincidence of enrichments of these elements and of $\mathrm{Hg}$ are due to control of sequential hydrothermal events by the same structures. 
CASE STUDY OF THE BEOWAWE GEOTHERMAL SYSTEM

Bruce S. Sibbett

Joseph N. Moore

Phillip M. Wright

In Preparation

Journal Article

\section{ABSTRACT}

The Beowawe geothermal system in northern Nevada is a structurally controlled, water dominated resource with a measured temperature of $212^{\circ} \mathrm{C}$ $\left(414^{\circ} \mathrm{F}\right)$. A large active opaline sinter terrace is present along a Tertiary normal fault escarpment. Several companies have explored the area and a considerable volume of surface and subsurface data is not available on the resource. The thermal fluids occur in a $1,220 \mathrm{~m}$ (4000 feet) thick Tertiary volcanic rock section and the underlying quartzite and argillite of the Ordovician Valmy Formation and flow to the surface along southwest and northwest trending faults. Measured temperatures and geothermometers yield a reservoir temperature of about $210^{\circ} \mathrm{C}$.

Surface alteration associated with the geothermal system has strong vertical zoning along the Malpais escarpment. Subsurface alteration is less clearly defined but general ly increases with depth within the volcanic rocks. 


\section{GEOLOGY OF THE TUSCARORA GEOTHERMAL PROSPECT}

ELKO COUNTY, NEVADA

Bruce S. Sibbett

In Preparation

Journal Article

Geological Society of America Bulletin

DOE/ID/12079-33

\section{ABSTRACT}

The Tuscarora geothermal prospect is located at the north end of Independence Val ley in northern Nevada. Thermal springs issue from 01 igocene tuffaceous sediments near the center of an area of high thermal gradient. The springs are associated with a large siliceous sinter mound and are currently depositing silica and calcium carbonate. Measured fluid temperatures range up to $95^{\circ} \mathrm{C}$ and chemical geothermometers indicate a reservoir temperature of $216^{\circ} \mathrm{C}$. The Independence Valley contains 35 to $39 \mathrm{~m} . \mathrm{y}$. old tuffs and tuffaceous sediments which overlie Paleozoic clastic and volcanic rocks and are overlain by Miocene lava and pyroclastic flows. The rocks have been deformed by normal faults trending north-south and northwest and by folds trending north-south which have been active in the Pleistocene. 


\section{PART II}

REPORTS CONSIDERED TO BE AN INDIRECT RESULT OF THE INDUSTRY COUPLED PROGRAM

TITLE - as presented in the present format

AUTHOR(S)

DATE - date is when report was printed and may not reflect the written or delivered date

FORMAT - ESL report designates an origin with the Earth Science Laboratory UUGG designates an origin with the Department of Geology and Geophysics, University of Utah

JOURNAL designates an article published by, in press by, or submitted to the scientific journal indicated

REPORT NUMBER - the DOE-designated number by contract and the ESL report number in parentheses

ABSTRACT - abstract, introduction or first page of an article 
HYDROTHERMAL ALTERATION AT THE ROOSEVELT HOT SPRINGS THERMAL

\title{
AREA, UTAH: PETROGRAPHIC CHARACTERIZATION OF
}

THE ALTERATION TO 2 KILOMETERS DEPTH

\author{
J. M. Ballantyne \\ W. T. Parry
}

Apri1 1978

UUGG Report

DOE/ET/28392-1

\section{ABSTRACT}

Hydrothemal alteration in drill cuttings from Thermal Power drill hole 14-2, Roosevelt Hot Springs Thermal area, has been studied petrographically. The hole is sited in alluvium approximately $1.6 \mathrm{~km}$ southeast of the old Resort and was rotary drilled to a depth of $1866.0 \mathrm{~m}$. The exact hole location is $2310 \mathrm{FNL}, 350 \mathrm{FWL}$, Sec. 2, Twp 27S, Rge 9W, elevation $1908.5 \mathrm{~m}$. Core was extracted from 792.5 to $795.5 \mathrm{~m}$. Thin sections were made from samples at 15.2 $m$ intervals of drill cuttings collected at 1.5 or $3.0 \mathrm{~m}$ intervals during drilling. Thin sections were made of 1.5 or $3.0 \mathrm{~m}$ intervals from 274.3 to $304.8 \mathrm{~m}, 487.9$ to $581.2 \mathrm{~m}$, and 868.7 to $899.2 \mathrm{~m}$. These intervals were chosen for close-spaced sampling on the basis of increases in temperature, porosity, conductivity and acoustic velocity shown in geophysical logs. A total of 153 thin sections of cuttings were made, and an additional 9 sections were made fram the core. Depth of thin section samples are 1isted in the appendix. A visual estimate of the percentage of each rock type was made for each thin section. 
A SUMMARY OF THE GEOLOGY, GEOCHEMISTRY, AND GEOPHYSICS

OF THE ROOSEVELT HOT SPRINGS THERMAL AREA, UTAH

\author{
S. H. Ward \\ W. T. Parry \\ W. P. Nash \\ W. R. Sill \\ F. H. Brown \\ J. A. Whelan \\ J. R. Bowman \\ June 1978 \\ Journal Article \\ Geophysics
}

\title{
ABSTRACT
}

The Roosevelt Hot Springs thermal area is a newly discovered geothermal power prospect in Utah. Seven production wells have been drilled with a maximum per-well flow capabil ity averaging $4.5 \times 10^{5} \mathrm{~kg}$ of combined vapor and liquid per hour at a shut-in bottom hole temperature near $260^{\circ} \mathrm{C}$.

The thermal area is located on the western margin of the Mineral Mountains, which consist dominantly of a Tertiary granitic pluton $32 \mathrm{~km}$ long by $8 \mathrm{~km}$ wide. Rhyolitic tuffs, flows, and domes cover about $25 \mathrm{~km}^{2}$ of the crest and west side of the Mineral Mountains within $5 \mathrm{~km}$ of the thermal area. The rhyolitic volcanism occurred between 0.8 and $0.5 \mathrm{m.y}$. ago and constitutes a major pleistocene thermal event believed to be significant to the evaluation of the Roosevelt Hot Springs thermal area. Thermal waters of the (now) dry spring, a seep, and the deep reservoir are dilute (ionic strength 0.1 to 0.2 ) sodium chloride brines.

Spring deposits consist of siliceous sinter and minor sulfur. Alluvium is cemented by sinter and altered in varying degrees by hot, acid-sulfate water to opal and alunite at the surface, grading successively to alunitekaolinite, alunite-kaolinite-montmorillonite, and muscovite-pyrite within $60 \mathrm{~m}$ of the surface. Observed alteration and water chemistry are consistent with a model in which hot aqueous solutions containing $\mathrm{H}_{2} \mathrm{~S}$ and sulfate convectively rise along major fractures. Hydrogen sulfide oxidizes to sulfate near the surface decreasing the $\mathrm{pH}$ and causes alunite to form. Opal precipitates as the solutions cool. Kaolinite, muscovite, and $K$-feldspar are formed in sequence, as the themal water percolates downward and hydrogen ions and sulfate are consumed.

Major swarms of earthquakes occur $30 \mathrm{~km}$ to the east-northeast near Cove Fort, Utah, but only minor earthquake activity occurs near the Roosevelt Hot Springs thermal area. Del ayed $P$-wave travel times generated from the Cove Fort microearthquakes, and observed west of the northern Mineral Mountains, are suggestive of a low-velocity zone beneath the Mineral Mountains; the vertical and lateral resolution of the data is inadequate to delineate the zone. Gravity and magnetic surveys are useful in determining the structure 
and depth of valley fill of the area of the northern Mineral Mountains, but neither one has detected an igneous intrusive source of heat. Thermal gradient measurements that range up to $960^{\circ} \mathrm{C} / \mathrm{km}$ in 30 to $60 \mathrm{~m}$ deep holes outline a 6 by $12 \mathrm{~km}$ thermal field. Heat flow and resistivity data both outline anomal ous zones along a system of faults that controls the nearsurface fluid flow. The source of heat is interpreted to be the convective circulation of thermal water. The lowered resistivity is due to the hot brine and the associated hydrothermal alteration. Magnetotelluric data are highly anomal ous over the field but means for their quantitative interpretation are unavailable at present; the anomalous data could as readily be interpreted as due to surface conductors as deep conductors which one might like to associate with a source of heat.

Any current model of the subsurface is highly speculative but can be expected to improve once existing seismic refraction and magnetotelluric data are fully interpreted. Then multiple-data-set modeling, combined with subsurface control from existing wells, should result in a reasonable model of the geothermal system. This modeling will be aided also by hydrologic, isotopic, structural, and additional P-wave delay studies currently in progress.

Based upon this case history, an explortion sequence appropriate to the eastern Basin and Range province should consist of phase 0 , a digest and synthesis of available data; phase 1, a regional a irphoto accumulation and analysis; phase 2, regional geologic mapping, regional radiometric dating of all intrusive and extrusive rocks, regional isotopic and chemical analysis of waters, regional aeromagnetic and gravity surveys, and regional collection of themal gradients in available holes; phase 3 , heat flow measurements in strategically located holes; phase 4, dipole-dipole resistivity surveys; phase 5, petrological, mineral ogical, and geochemical studies on cuttings and cores from heat flow drill holes; phase 6 , model test drilling accompanied by petrological, chemical, and isotopic analyses of cuttings and cores plus chemical and isotopic analyses of fluids; phase 7, detailed seismic refraction and reflection surveys; and phase 8, modeling and synthesis of all available data. 


\section{GE OCHEMISTRY OF SOLID MATERIALS FROM TWO U. S. GEOTHERMAL}

SYSTEMS AND ITS APPLICATION TO EXPLORATION

Robert W. Bamford

July 1978

ESL Report

Final $77-14$ (ESL-6)

\section{ABSTRACT}

This paper describes initial development of geochemical techniques for exploration and exploitation of geothermal systems. The techniques are based on analysis of solid materials. Distributions of $\mathrm{Cu}, \mathrm{Mo}, \mathrm{Pb}, \mathrm{Zn}, \mathrm{Ag}, \mathrm{As}, \mathrm{Sb}$, $\mathrm{Co}, \mathrm{Ni}, \mathrm{Mn}, \mathrm{Fe}, \mathrm{Bi}, \mathrm{B}, \mathrm{Te}, \mathrm{In}, \mathrm{Sn}$, and $\mathrm{W}$ are determined and evaluated for several sample types in a hot water system (Roosevelt Hot Springs, Utah) and a vapor dominated system (Geysers, California). The sample types analyzed are magnetic fractions, whole rock samples, and two different heavy liquid separates derived from cuttings composites from geothermal wells and shallow rotary drill holes. The results show that multi element geochemical zoning is developed at both a relatively small scale of over hundreds of feet around individual steam entries (SEs) and hot water entries (HWEs) in geothermal wells, and at a larger scale of over thousands of feet both vertically and lateral ly in geothemal systems. Zoning is surprisingly similar for both hotwater and vapor-dominated systems. Trace elements which display the most consistent and useful zoning characteristics are $\mathrm{As}, \mathrm{Sb}, \mathrm{Pb}, \mathrm{Zn}, \mathrm{Mn}, \mathrm{B}$, and W. Opt imum delineation of the zoning is provided by +3.3 heavy liquid (HL) samples compared to the other sample types evaluated. Utilization of +3.3 samples maximizes detection of hydrothermal trace elements and markedly reduces or eliminates chemical signatures specifically related to rock type.

In small-scale zoning around HWEs and SEs, As, Sb, B(?), and W(?) are concentrated at or very close to the entries and $\mathrm{Pb}$ and $\mathrm{Mn}$ are concentrated between entries or, for $\mathrm{Pb}$ at least, near cold water entries (CWEs). Pyrite abundance is generally greatest at or near HWEs and SEs and has a roughly antithetical relationship to overall magnetite distribution. Much $\mathrm{Fe}$ in the pyrite has probably been derived from magnetite which presumably is mainly non-hydrothermal in origin.

Large-scale zoning, both vertical and lateral, is apparently characterized by $\mathrm{As}, \mathrm{Sb}, \mathrm{B}(?)$, and $W(?)$, concentration in zones closest to the thermal anomaly and $\mathrm{Zn}, \mathrm{Mn}(?)$, and $\mathrm{Mo}_{0}(?)$ concentration in peripheral zones. $\mathrm{Pb}$ is more closely associated with As near the thermal anomaly, but may occupy an intermediate zone close to and possibly overlapping the periphery of the high As zone. Comparison of large-scale lateral zoning results for Roosevelt with thermal gradient data shows a good correlation of high As anomalies with high thermal gradients $\left(>100^{\circ} \mathrm{C} / \mathrm{km}\right)$ and of high $\mathrm{Zn}$ anomalies with lower thermal gradients $\left(<100^{\circ} \mathrm{C} / \mathrm{km}\right)$.

Several important applications of these geochemical results to problems 
of exploration and exploitation of geothermal systems could be attempted during the FY 1978 and 1979 period. These include use for

(1) location of steam or hot water entries in newly drilled geothermal wells,

(2) definition of general and possibly specific drilling targets, and

(3) prediction of approach to steam or hot water entries especialiy in order to facilitate decisions on additional drilling in subcommercial wells as planned total depth is approached.

Such applications could significantly contribute to power on stream in 1985 and to cost effectiveness in achieving this goal.

A considerable amount of additional work is required to optimize methods, corroborate results, and make some of these applications routine. Much will be accomplished during FY 1978, but continuation into FY 1979 and 1980 at the present level of effort is required to adequately complete the project. Information to be obtained on depositional processes to aid understanding of the geochemical results should be of significant value in dealing with reservoir engineering problems. Work of this description could be expanded to specifically deal with such problems. 
HYDROTHERMAL ALTERATION AT THE ROOSEVELT HOT SPRINGS THERMAL AREA, UTAH: MODAL MINERALOGY, AND GEOCHEMISTRY OF SERICITE, AND FELDSPAR FROM ALTERED ROCKS, THERMAL POWER COMPANY

WELL UTAH STATE 14-2

J. M. Ballantyne

November 1978

UUGG Report

$\mathrm{DOE} / \mathrm{ET} / 28392-16$

\section{ABSTRACT}

Sericites, chlorites, feldspars, biotite and hornblende from hydrothermally altered rocks at several depths in Themal Power Company well Utah State 14-2, Roosevelt Hot Springs Thermal Area, Utah, have been analysed using the electron microprobe. Sericites and ferromagnesian minerals have been analysed for 12 major elements, and feldspars for 3 . The results have been used, al ong with whole rock chemical analyses, to computer calculate modal mineralogy for samples from the drill hole. Calculated modes for hydrothermal minerals are in reasonable agreement with observations from thin sections.

Chl grite compositjons plotted in terms of ions on a graph of $\mathrm{Si}^{4+}$ versus $\mathrm{Mg}^{2+} /\left(\mathrm{Mg}^{2+}+\mathrm{Fe}^{2+}+\mathrm{Fe}^{3+}\right)$ fall in the ripidolite-pycnochlorite-brunsvigite field and show distinct differences due to host mineral type. Tetrahedral occupancy in chlorite by $\mathrm{Si}^{4+}$ lons increases according to host mineral in the order: biotite, plagioclase, hornblende; and octahedral occupancy by $\mathrm{Mg}^{2+}$ ions increases in the order: plagjoclase, hornblende, biotite. A ternary pl ot of $\mathrm{Mg}^{2+}, \mathrm{Fe}^{2+}+\mathrm{Fe}^{3+}$, and $\mathrm{Al}^{3+}$ ions in octahedral positions shows a less distinct effect of host mineral control. No systematic compositional trends within the dril. 1 hole are evident but compositions do vary with depth.

Sericites replace plagioclase and rarely biotite. No host mineral effect is evident. All of the sericites are phengitic, having $S i^{4+}: \mathrm{Al}^{3+}$ ratios greater than $3: 1$, and $S i^{4+}$ content shows an overall downhole increase with depth in the driil hole. An overall downhole decrease is exhibited by $F^{-}$ relative to $\mathrm{Mg}^{2+}$. 
HYDROTHERMAL ALTERATION AT THE ROOSEVELT HOT SPRINGS THERMAL AREA, UTAH: CHARACTERIZATION OF ROCK TYPES AND ALTERATION

IN GETTY OIL COMPANY WELL UTAH STATE 52-21

\author{
G. H. Ballantyne \\ November 1978 \\ UUGG Report \\ DOE/ET/28392-12
}

\title{
ASBSTRACT
}

Getty 0 il Company well 52-21 in the Roosevelt Hot Springs thermal area was drilled to 7500 feet in predominantly upper amphibolite facies metamorphic rocks. All lithologies in the drill hole are pervasively but weakly altered: the alteration assemblage is chlorite + sericite + clays with occasional traces of calcite, above 2300 feet, and chlorite + sericite + clays + calcite \pm epidote below 2500 feet. A zone of increased alteration intensity from approximately 1800 feet to 2300 feet occurs within and adjacent to a dacite dike which cuts the metamorphic rocks. A second zone of stronger alteration extends from 6000 feet to the bottom of the drill hole.

The drill hole which is located approximately 5000 feet south of the center of the silica apron known as the Opal Mound was apparently drilled beyond the influence of acid, high-sulfate brines such as have affected the upper portions of drill holes 72-16,76-1 and University of Utah IA and $1 B$. 
RADON EMANOMETRY AS A GEOTHERMAL

EXPLORATION TECHNIQUE: THEORY AND AN EXAMPLE

FROM ROOSEVELT HOT SPRINGS KGRA, UTAH

D. L. Nielson

December 1978

ESL Report

DOE/ET/28392-18 (ESL-14)

\section{ABSTRACT}

$\mathrm{Rn}^{222}$ is the longest-lived radon isotope and has gommonly been used as a geologic tracer. This isotope is a product of the $U^{238}$ decay series and is present in some amount in all geologic systems. From published literature, radon flux in geothermal systems is evaluated in terms of: 1) the formatin of radon by disintegration of parent material and the release of radon from the crystalitine structure, ang 2 ) the movement of radon through diffusion and transport processes. $\mathrm{Rn}^{222}$ originates from the decay of $\mathrm{Bg} 226$ which emits an alpha particle. The recoil energy of the newly formed $\mathrm{Rn}^{222}$ is sufficient to transport the atom $0.03-0.04 \mathrm{~m}$ in rocks. This is the principal method of release of $\mathrm{Rn}$ from the rock matrix. It has been found that the amount of rad on contributed to geofluids is inversely proportional to the particle size and the flux is thus increased in areas of fracturing.

Because of the short half-1ife of $\mathrm{Rn}^{222}$ and slow rates of diffusion, a transport mechanism must predominate if radon is to migrate appreciable distances. In the near-surface environment, transport processes are dependent on atmostpheric variables including barometric pressure, wind velocities, and precipitation. These factors are very difficult to quantify but they can be compensated for by integrating the radon flux over time.

Four radon survey 1 ines were established over the geothermal field of Roosevelt Hot Springs KGRA. The radon flux was determined using the Westinghouse Alpha 2 system which measures the flux at each station over a period of 30 days using an alpha-sensitive dosimeter. The method was very successful in locating mapped fault systems that communicate with the structurally controlled geothermal reservoir. It is concluded that this method, coupled with a structural analysis, can be useful as a site-specific exploration tool, particularly in locating exploration holes in known geothermal areas. 


\author{
INITIAL INVESTIGATION OF SOIL \\ MERCURY GEOCHEMISTRY AS AN AID TO \\ DRILL SITE SELECTION IN GEOTHERMAL SYSTEMS \\ R. M. Capuano \\ R. W. Bamford
}

December 1978

ESL Report

DOE/ET/28392-20 (ESL-13)

\begin{abstract}
A mercury-in-soil survey was conducted at the Roosevelt Hot Springs Known Geothermal Resource Area (KGRA), Utah, to evaluate mercury soll geochemistry as a method of selecting exploration well sites in a hot-water geothermal system. Samples of -80 mesh soil were collected at $30.5 \mathrm{~m}$ intervals along traverses crossing known structures, surficial geothermal alteration, and exploration well 1 sites, and were analysed using a Model 301 Gold Film Mercury Detector (Jerome Instrument Corp., Jerame, Arizona).

Strong mercury anomalies occur at locations along known structures in close proximity to subsurface thermal activity; examples include areas over hot spring deposits and near a shallow producing well. In contrast, background mercury concentrations are present in nearby locations with little or no indication of subsurface thermal activity, such as areas around deep marginal producing wells and dry wells, and areas lacking hot spring deposits. These results indicate that mercury geochemical surveys can be useful for identifying and mapping structures controlling fluid flow in geothermal systems and for delineating areas overlying near-surface thermal activity. Soil mercury geochemistry thus provides information which may aid in the cost-effective selection of exploratory well sites.
\end{abstract}


STABLE ISOTOPE INESTIGATION OF FLUIDS AND WATER-ROCK

INTERACTION IN THE ROOSEVELT HOT SPRINGS THERMAL AREA, UTAH

J. R. Bowman

January 1979

UUGG Report

Topical $77-10$

\section{ABSTRACT}

Carbon-hydrogen-oxygen isotope compositions have been measured in regional cold waters, geothermal fluids, and hydrothermally altered rocks from the Roosevelt Hot Springs geothermal area. These data have been used, in conjunction with other geological and geochemical data from this geothermal system, to place some limits on the origin of geothermal fiuids and reservoir carbon, the fluid recharge area, physical-chemical environment of hydrothermal alteration, and relative permeability of the geothermal system. The similarity of hydrogen isotope compositions of local meteoric water and geothermal reservoir fluid indicate that the geothermal fluids are virtually entirely of surface derivation. An isotopically reasonable source area would be the Mineral Mountains directly to the east of the Roosevelt system. Hydrothermal calcite appears to be in isotopic equilibrium with the deep reservoir fluid. The $\delta C^{13}$ values of deep calcites and $\mathrm{T}-\mathrm{pH}-\mathrm{fO}_{2}$ conditions of the reservoir defined, by measured temperature, fluid chemistry, and alteration mineralogy $f i x$ the $\delta^{13} C$ value of the geothermal system to -5 to $-6.5 \%$ $(P D B)$. These values do not unambiguously define any one source or process, however. There is a relatively small increase in ${ }^{18} 0$ of geotherpl 1 fluids relative to their cold surface water precursors and significant 180 depletion accompanying hydrothermal alteration of the granitic host rock. These isotopic shifts indicate a high ratio of geothermal fluid to al tered rock for the geothermal system, implying relatively rapid (geologically) recirculation rates and significant permeability of the geothermal system. 
SELF POTENTIAL SURVEY, ROOSEVELT HOT SPRINGS, UTAH

\author{
W. R. Sill \\ D. S. Johng \\ January 1979 \\ UUGG Report
}

DOE/ET/28392-21

\title{
ABSTRACT
}

A large-scale $\left(35 \mathrm{~km}^{2}\right)$ self potential (SP) survey was made at Roosevelt Hot Springs. The survey consisted of approximately $47 \mathrm{line}-\mathrm{km}$ of profiles at station spacings of $100 \mathrm{~m}$. The profiles were run using a fixed electrode and a traveling electrode out to distances of 1 to $2 \mathrm{~km}$, before advancing the fixed el ectrode up to the last occupied station. Repeated measurements show a standard deviation of about $\pm 6 \mathrm{mv}$, although the spread on groups of measurements might be as large as $30 \mathrm{mv}$.

Some of the SP profiles show correlations with the thermal system, having general ly low values over the thermal high and the coincident resistivity low. Some of the smaller scale features appear to be associated with mapped faults. In plan view, the contoured self potential shows a character very similar to the $300 \mathrm{~m}$, dipole-dipole resistivity. The SP values are generally low, where the resistivity is low. Along the eastern margin of the system, in the vicinity of steep resistivity gradietns, the contour map shows a series of localized highs.

Electrokinetic (streaming potential) and thermoelectric effects are likely candidates for the sources of these self potential anomalies. The (near surface) hydrothermal clay alteration should increase the cross coupling coefficients for these two effects, although excess $\mathrm{clay}$ alteration may reduce the effects through the reduction in electrical resistivity.

Thermoelectric effects, combined with vertical temperature gradients or spherical or point sources bel ow the clay alteration zone (large coupling coefficient), generally produce positive SP anomalies. Negative thermoel ectric anomalies can be produced by point sources within the cross coupling zone (clay alteration), but this would probably be limited to relatively shallow sources (less than hundreds of meters). On the other hand, electrokinetic effects combined with various spherical or point sources general ly produce negative anomalies. For this reason, the electrokinetic effects might be favored as the source of the large-scale low region. Other sources or geometries might be postulated for the localized highs, but their proximity to the steep resistivity gradients might suggest a cause related to the electrical structure. 


\author{
SUMMARY OF POTASSIUM/ARGON \\ AGE DATING--1979 \\ Stanley H. Evans, Jr. \\ January, 1980 \\ UUGG Report \\ DOE/ET/28392-41
}

\title{
ABSTRACT
}

During FY-79 the K/Ar dating laboratory at the Department of Geology and Geophysics of the University of Utah became operational. During the past calendar year forty-seven dates have been produced from areas predominantly in Utah. Dating has also been done to support University of Utah Research Institute/Earth Science Laboratory programs on areas in Nevada and Montana through the State Coupled program and Case Studies Support program.

Areas in which activity was concentrated include:

Cove Creek Domes/Twin Peaks Area, SW Utah. Here volcanic activity spanned the time from 2.74 to 2.27 M.Y., with a mean age of $2.47 \pm 0.17$ M.Y.

Black Rock Desert, SW Utah. Two dates on a single flow indicate an age. of $1.50 \pm 0.10$ M.Y. for a flow previously undated.

Wildcat Creek Area, SW Utah. Dating of rhyolite flows from this area gives a mean age of volcanism of $9.38 \pm 0.11$ M.Y., considerably older than previously inferred by the work of Haugh (1978).

Mineral Mountains Pluton, SW Utah. Twelve dates on phases of the pluton indicate a complex history of intrusion, and more work is indicated in order to derive a coherent picture of the magmatic events leading to the formation of this batholith.

Blackfoot Reservoir, Idaho. Two dates on rhyolite domes, previously undated, give ages of $1.59 \pm 0.06 \mathrm{M} . \mathrm{Y}$. and $1.41 \pm 0.15 \mathrm{M.Y}$.

In addition to the previous dating activity, ages of units in areas of interest in Nevada have been obtained. These areas include Beowawe, San Emidio, and Soda Lake. This work was done under the Industry Coupled Program. Four samples were also dated for the Montana Geological Survey as part of the State Coupled Program. 


\author{
MULTIELEMENT GEOCHEMISTRY OF SOLID MATERIALS IN \\ GEOTHERMAL SYSTEMS AND ITS APPLICATIONS \\ PART 1: THE HOT-WATER SYSTEM AT THE \\ ROOSEVELT HOT SPRINGS KGRA, UTAH \\ Robert W. Bamford \\ Odin D. Christensen \\ Regina M. Capuano
}

February, 1980

ESL Report

DOE/ET/27002-7 (ESL-30)

\begin{abstract}
Geochemical studies of the geothermal system at Roosevelt Hot Springs, Utah, have led to development of chemical criteria for recognition of major features of the system and to a three-dimensional model for chemical zoning in the system. Based on this improved level of understanding, several new or modified geochemical exploration and assessment techniques have been defined and are probably broadly applicable to evaluation of hot-water geothermal systems.
\end{abstract}

The main purpose of this work was the development or adaptation of solids geochemical exploration techniques for use in the geothermal environment. The approach used was multielement geochemical analys is of solid samples including soils, whole rock materials, and +3.3 specific gravity fractions derived by heavy liquid separation from the whole rock material. Whole rock materials were predominantly suites of contiguous 10-foot cuttings samples from geothemal wells, but al so included suites of cuttings samples from temperature gradient drill holes, diamond drill core, and surface rock samples. A broad spectrum of major, minor, and trace elements was determined for these samples and used to establish spatial associations of hydrothermal element enrichments and depletions relative to critical geothermal features.

Principal zones distinguished in the geothermal system are a reservoir zone which encompasses al 1 rock with high-temperature $\left(>400^{\circ} \mathrm{F}\right)$ reservoir potential, a self-sealed zone developed at and beyond the reservoir zone margin and which is gradually encroaching on the reservoir, and a peripheral zone developed within and beyond outer parts of the self-sealed zone. Hydrothermal el ement enrichments which characterize these zones are As, Li, $\mathrm{Be}$, and $\mathrm{Zn}$ (and probably $\mathrm{Fe}, \mathrm{Mg}, \mathrm{Cr}, \mathrm{P}, \mathrm{Co}, \mathrm{Ni}, \mathrm{Cu}, \mathrm{Zr}, \mathrm{La}$, and $\mathrm{Ce}$ ) in the reservoir zone, especially at hot-water entries; $\mathrm{Hg}$ plus the reservoir zone assemblage (less $\mathrm{Zn}$ ?) in inner parts of the self-sealed zone; $\mathrm{Hg}, \mathrm{Mn}$, and $\mathrm{Zn}$ plus the reservoir zone assemblage in outer parts of the self-sealed zone; and $\mathrm{Mn}$ and $\mathrm{Zn}$ (and possibly $\mathrm{W}$ and $\mathrm{Mo}$ ) in the peripheral zone. $\mathrm{Na}, \mathrm{Sr}$, and possibly $\mathrm{Ba}$ are variably depleted from rock in the immediate vicinity of hot water entires within the reservoir zone and inner self-sealed zone. Minor $\mathrm{Hg}$ enrichments are developed locally in the reservoir but are generally several 
orders of magnitude smaller than those which characterize the self-sealed zone.

The Roosevlet zoning model appears to be broadly applicable to other hotwater geothermal systems based on partially documented similarities in hydrothermal element distributions for a few of these systems, general similarities in thermal water chemistry for many systems, and tentatively inferred causes of key element deposition. The model thus provides a basis for establishing solids geochemical techniques applicable to the exploration and assessment of hot-water goethermal systems in general. Three multielement techniques, detailed soil surveys (or surface rock sampling), large-scale "surface" surveys utilizing shallow drill hole cuttings samples (commonly temperature gradient hole cuttings), and geochemical logging of deep drill holes, are indicated to be useful. These techniques, especially the geochemical logging, are shown to offer potentially high cost-effectiveness and, consequently, can be recammended for initial routine use.

The zoning model can possibly be utilized to provide insights into the nature and geonetry of vapor-dominated systems evolved from hot-water systems, but otherwise is expected to have only limited applicability to these systems. 
S. H. Evans, Jr.

F. H. Brown

November, 1980

UUGG Report

$D O E / I D / 12079-23$

\section{ABSTRACT}

During FY80 a significant improvement in efficiency of the K-Ar laboratory was brought about by completion of a second extraction line. Two extractions can now be done routinely each day and the ${ }^{38} \mathrm{Ar}$ spike ratios of the new table will permit dating of much younger samples than previously.

Extensive $K-A r$ dating of samples from the Mineral Mountains shows intervals of silicic volcanism at $0.5,0.8$ and $7.5 \mathrm{~m} . \mathrm{y}$. K-Ar dating of plutonic units does not present a consistent picture, however. Plutonic events $35-40$ m.y., 29 m.y. and 19-21 m.y. ago are suggested but interpretation must be considered prel iminary. Joint programs with the U.S. Geological Survey now underway to study the Rb-Sr and U-Pb systematics of the Mineral Mountains pluton should aid in unravelling its history.

Dating of basaits from the Cove Creek Domes/Twin Peaks area, Utah, has aided in delineating the timing of basaltic volcanism. This adds to the al ready extensive data on the chronology of volcanic activity in the area.

Dating of samples from the Beowawe known Geothermal Resources Area, Nevada have confirmed earlier dates indicating major vol canism took place 38 m.y. ago and 17-16 m.y. ago.

The State Coupled Program to assess geothermal potential of areas such as the Cascades has brought about an influx of samples from Oregon, Washington and Montana. Twenty-six samples were dated in support of the program this year. 
INTERPRETATION OF DRILL CUTTINGS

FROM GEOTHERMAL WELLS

Jeffrey B. Hulen

Bruce S. Sibbett

June, 1981

ESL Report

DOE/ID/12079-36 (ESL-57)

\section{PREFACE}

Drill cuttings, which by comparison with core are relatively inexpensive and easy to obtain, are the samples typically collected from geothermal wells. They are the principal source of the direct downhole geologic information essential for a successful subsurface investigation.

Cuttings, however, can be far more difficult to interpret than core. They are finely ground and mixed, commoniy contaminated samples of formerly more or less coherent rock, and they can present special interpretation problems. These problems, and methods to help solve them, are discussed in this outline, which is also published as part of Geothermal Resources Council Technical Training Course No. 7, "Introduction to Geothermal Log Interpretation" (Hulen and Sibbett, 1981). 


\section{K/Ar AGES OF THE PYRAMID SEQUENCE IN THE VICINITY OF THE SAN EMIDIO GEOTHERMAL AREA, WASHOE COUNTY, NEVADA \\ S. H. Evans, Jr. J. N. Moore \\ M. C. Adams}

August 1981

Journal Article

ISOCHRON/WEST

DOE/ET/12079-52

\section{ABSTRACT}

As part of the Department of Energy's program to evaluate the geothermal potential of various areas in the western states, personnel of the University of Uth Research Institute, Earth Science Laboratory and the University of Utah Department of Geology and Geophysics undertook a joint geologic, geophysical, and geochronological study of the San Emidio geothermal system. The San Emidio thermal area lies adjacent to the northern end of the Lake Range, approximately 15 miles south of Gerlach, Nevada. Figure 1 presents a generalized geologic map of the area along with sample locations for material dated. Previous work in the area includes the thesis of Bonham (1962) and a report on the reconnaissance geology of Washoe County, also by Bonham (1969). Further reconnaissance mapping was conducted by one of the authors (Moore, 1980) under Department of Energy sponsorship. A detailed discussion of geology and geothermal potential of the area was presented by Mackelprang and others (1980).

The purpose of this paper is to present $K-A r$ ages of volcanic rocks which are exposed in the Lake Range and underlie the San Emidio Desert. Although the volcanic rocks are too old to be related to the heat source which drives the San Emidio geothermal system, the K-Ar ages nevertheless provide new insight into the timing of andesitic volcanism and Basin and Range faulting in northern Nevada. 
SUMMARY OF POTASSIUM/ARGON DATING--1981

\author{
Stanley H. Evans, Jr. \\ Francis $H$. Brown \\ September, 1981 \\ ESL Report
}

DOE/ ID / $12079-45$

\begin{abstract}
This report summarizes the analytical results for the last fiscal year effort in potassium/argon dating in support of $U$. S. Department of Energy programs. Nearly 100 new dates have been generated, the vast majority of which were for the Oregon Department of Geology and Mineral Industries. Other institutions which al so received dating services were: Earth Science Laboratory, University of Utah Research Institute; Department of Geology and Geophysics, University of Utah; Montana Geological Survey; Portland State University; and Southland Royalty Company.

Recal ibration of the argon extraction tables resulted in refinement of values for tracer ratios and depletion constants for our two extrgctiog
lines. Tracer ratios are $(36 \mathrm{Ar} / \mathrm{Ar}) \mathrm{Ar}=0.0308$ and $0.0000449 ;\left(\mathrm{Ar}_{\mathrm{Ar}}\right)_{\mathrm{T}}=$ 0.0501 and 0.0014 for extraction tabies 1 and 2 , respectively. Tracer depletion constants are -0.0002250 and -0.0005501 for tables $i$ and 2 , respectively. Initial values for the argon tracer pipettes are $3.2522 \times 10^{-11}$ moles and $3.0320 \times 10^{-11}$ moles for tables 1 and 2 , respectively.
\end{abstract}


GEOCHEMICAL INDICATORS OF A HIGH-TEMPERATURE GEOTHERMAL SYSTEM

\author{
J. N. Moore \\ R. M. Capuano \\ 0. D. Christensen \\ May 1982 \\ Journal Article \\ 9th International Geochemical Exploration Symposium \\ DOE/ID/12079-49
}

\begin{abstract}
The intensity and distribution of hydrothemal alteration are frequently used during the exploration and assessment of a geothermal prospect to estimate the size, shape and temperature of a thermal system. Geochemical and petrographic observations used to characterize hydrothermal alteration include the mapping of both trace and major element dispersion patterns and of the distribution of secondary mineral assemblages.

This paper describes the trace element and mineralogical distributions common to many of the high-temperature systems $\left(>150^{\circ} \mathrm{C}\right)$ that we have studied.
\end{abstract}




\author{
HYDROGEN AND OXYEN ISOTOPE GEOCHEMISTRY OF COLD AND \\ WARM SPRINGS FROM THE TUSCARORA, NEVADA THERMAL AREA \\ J. R. Bowman \\ D. R. Cole \\ June 1982 \\ UUGG Report
}

DOE/ID/12079-70

\begin{abstract}
Eighteen cold and warm spring water samples from the Tuscarora, Nevada KGRA have been analyzed for hydrogen and oxygen isotope composition and fluid chemistry. Wam springs have 80 values $(-128$ to -137 permil) significantly lower than those of cold springs to the north and east of the area, but similar to the $S D$ values of cold springs to the west and south $(-131$ to -135 permil). The recharge area for the warm springs is unlikely to be to the immediate north, which is the local topographic highl and in the area. The hydrogen isotope data would permit recharge from areas to the southwest or from high el evations to the southeast (Independence Mountains), a sector consistent with electrical resistivity evidence of fluid flow.

Warm springs are $\mathrm{HCO}_{3}-$-rich waters, enriched by a factor of 3 to 10 in $\mathrm{Na}, \mathrm{HCO}_{3}{ }^{-}$and $\mathrm{SiO}_{2}$ relative to local cold springs. Average quartz (no steam loss) and $\mathrm{Na} / \mathrm{K} / \mathrm{Ca}$ geothemometer estimates suggest subsurface temperatures of $145^{\circ}$ and $196^{\circ} \mathrm{C}$, respectively. The warm springs exhibit poor correlations between either hydrogen or oxygen isotope composition and water temperature or chenistry. The absence of such correlations suggests that there is no single coherent pattern of cold water mixing or evaporation in the themal spring system.
\end{abstract}




\section{DIFFUSION COUPLED (ELECTROCHEMICAL) \\ SELF-POTENTIAL EFFECTS IN GEOTHERMAL AREAS}

W. R. Sil1

August 1982

UUGG Report

DOE/ID/12079-73

\section{ABSTRACT}

Electrochemical effects caused by the diffusion of geothermal brines are investigated as a possible source mechanism for the generation of selfpotential. One of the difficulties associated with the modeling of the coupled salt flow and electric current problem is that the coupled equations are nonl inear because the electrical conductivity depends on the ambient salt concentration. The linearized solutions correspond to the case where the concentration variations are small compared to the background concentration. The linear case is not of much interest in geothermal areas where the brines may be much more concentrated than the normal groundwater.

The investigation of the coupled transport problem in this paper shows that the solution of the salt flow probiem gives a concentration distribution that is very close to that derived from the solution of the ambipolar diffusion problem. In pure ambipolar diffusion, the local electric field is such that the cations and anions drift with the same velocity and the total electric current is zero. When ambipolar diffusion is an adequate description of the transport of solute ions, the salt flow and electric current problems can be solved in a manner analogous to the coupled fluid flow and heat flow problems as described in sill (1981, 1982a). The results of model calculations indicate that this mechanism can generate only small selfpotentials (_ $10 \mathrm{mv}$ ). 


\title{
EVOLUT ION OF THE QUATERNARY MAGMATIC SYSTEM, MINERAL MOUNTAINS, UTAH: INTERPRETATIONS FROM \\ CHEMICAL AND EXPERIMENTAL MODELING
}

\author{
W. P. Nash \\ H. R. Crecraft \\ October 1982 \\ UUGG Report \\ DOE/ID/12079-74
}

\section{ABSTRACT}

Major geothermal resources are associated with large silicic volcanic systems in the western United States. Among these are the Valles Caldera, New Mexico, Long Val ley and the Coso Mountains, California, and, on a smaller scale, the Mineral Mountains in Utah. Quaternary volcanism in the Mineral Mountains of west-central Utah shares many common characteristics with other centers of silicic volcanism in the western United States, and its chemical evolution over time is similar to chemical variations exhibited in compositionally zoned ash-flow tuffs. Compositionally zoned ash-flow tuffs have been widely recognized in the western United States (Williams, 1942; Lipman et a1., 1966; Hildreth, 1979) and are thought to have erupted from roof zones of compositional ly statified high-silica magmas. As an ash-flow tuff erupts, it taps progressively deeper levels of a zoned magma, and hence, it represents an instantaneous, inverted record of gradients in the upper portion of the magma chamber. The most thoroughly documented study of a zoned ashfl ow tuff is that of Hildreth $(1977,1979)$ on the Bishop tuff of Long Valley, California, which has served as a model of comparison for other areas. More recently, Crecraft et al. (1981) have documented the development over time of a similar high-silica zoned magma at the Twin Peaks rhyolite field in westcentral Utah. The chemical gradients in both the Twin Peaks and the Bishop tuff magmas are remarkably similar to those in the Mineral Mountains and are illustrated by the enrichment factors shown in Figure 1. Enrichment factors are ratios of concentrations in the most evolved rhyolite divided by concentrations in the least evolved rhyolite. Elements which plot upward are enriched upward in zoned magmas. These gradients are characterized by upward increases in volatiles, silicon, all alkalies other than potassium, heavy rare earths, and highly charged cations; and decreases in all alkaline earths heavier than beryllium, iron, titanium, aluminum, and light rare earths. other characteristic changes upward are decreases in temperature, oxygen fugacity, phenocryst content and density. The net density gradient, due primarily to the upward increase in water, is strongly stabilizing with respect to large-scale convection (Hildreth, 1979; Crecraft et al., 1981).

The origin of these compositional gradients has been problematical. In some areas such as the Paintbrush tuff in southern Nevada (Lipman et al., 1966) and Crater Lakes, Oregon (Williams, 1942; Ritchie, 1979) chemical data appear consistent with crystal fractionation. However, the high viscosity and correspondingly slow settling velocities, and the lack of physical evidence 
for crystal settling, severely constrain crystal settling as a mechanism for fractionation in high-silica systems. In other areas, such as the Jemez Mountains, New Mexico (Smith, 1979), the Bishop tuff (Hildreth, 1979), Sierra La Primavera, Mexico (Mahood, 1981), and at Twin Peaks, (Crecraft et al., $1979,1980,1981$ ), crystal fractionation apparently fails to account for the antithetic behavior of the 1 ight and heavy rare earth elements and for the extreme variations of many trace elements. Largely because of the apparent failure of crystal fractionation to account for the observed mineralogical and chemical gradients in the Jemez Mountains and in the Bishop tuff, Shaw et al. (1976) proposed a new mechanism of differentiation to generate these magmas which they referred to as "thermogravitational diffusion", or simply "liquidstate differentiation". This model is based on the supposition that compositional gradients result from an approach to steady-state conditions. A combination of various influences, which could include the thermal gradient, grvitational field, and changes in liquid structure, induces diffusive potentials on components which drive mass flux and promote formation of gradients. More recently, investigations into phenomena associated with double-diffusive convection have suggested that such mechanisms may be important in developing compositional stratification in magmas (Chen and Turner, 1980; MCBirney and Noyes, 1979). This report is concerned primarily with analyzing the chemical and physical processes associated with the devel opment of a stratified high-silica roof zone in the Mineral Mountains magma system, and with evaluating the evidence for liquid-state differentiation and double diffusive convection in this and similar systems. 


\author{
MERCURY - ITS ROLE IN THE EXPLORATION OF \\ VAPOR-DOMINATED GEOTHERMAL SYSTEMS \\ J. N. Moore \\ 0. D. Christensen \\ R. W. Bamford \\ Journal Article \\ Geothermal Resources Council Transactions
}

DOE/ID/12079-43

\begin{abstract}
Geothermal wells drilled to depths of up to $3 \mathrm{~km}$ in The Geysers steam field have provided an opportunity to examine, laterally and vertically, the distribution of $\mathrm{Hg}$ in an active vapor-dominated hydrothermal system.

Mercury is concentrated primarily in the outer, cooler portions of the thermal system. Heating experiments indicate that $\mathrm{Hg}$ is contained primarily in silicate minerals and that it is heat labile at reservoir temperatures of $240^{\circ} \mathrm{C}$. The relative depletion of $\mathrm{Hg}$ within the reservoir rocks compared to the margins of the field suggests that the distribution of this element can be used to guide exploration in poorly known portions of the field.
\end{abstract}




\section{PART III}

OPEN-FILED MATERIALS GENERATED THROUGH THE INDUSTRY COUPLED PROGRAM 
A11 the materials on this list have been generated under Department of Energy funding for the furtherance of geothermal exploration and development in the United States. Most of the material is raw exploration data from industry sources.

Prices in this list reflect minimum reproduction and mailing costs.

Al1 material is available for public viewing at the following locations:

All Utah, Nevada, and other materials:

Earth Science Laboratory

Library

420 Chipeta Hay, Suite 120

Salt Lake City, Utah

Marriatt Library Special Collections

University of Utah

Salt Lake City, Utah

Nevada Bureau of Mines and Geology

Library, Room 311

Scrugham Engineering Bldg.

University of Nevada

Reno, Nevada
U.S. Geological Survey

Public Enquiries Office

125 S. State, Room 8105

Federal Building

Salt Lake City, Utah

U.S. Geological Survey

Library

National Center

12201 Sunrise Valley Dr.

Reston, Virginia

Utah open-file materials only:

Utah Geological and Mineralogical Survey

Library

606 Blackhawk Way, Research Park

Salt Lake City, Utah 
Open-file materials generated under Department of Energy's Industry Coupled Program, and from Earth Science Laboratory research, are available in reproduction at duplicating and handling cost from:

Publications

Earth Science Laboratory

420 Chipeta Way, Suite 120

Salt Lake City, Utah 84108

$\underline{\text { OFR \# }}$

DESCRIPTION

COVE FORT-SULPHURDALE AREA, BEAVER AND MILLARD COS., UTAH

UT/CFS/ESL-1 Residual Aeromagnetic Map, 1:62,500, covering 190 sq mi in Dog Valley

0.75

UT/CFS/ESL-2 Same as above, at 1:24,000 on two sheets

UT/CFS/UOC-1 Union 0 il Co., general area studies:

.1 Temperature gradient study of 25 shallow holes 2.00

.2 Surface geology and geothermal manifestations $\quad 5.00$

.3 Seismic study $\quad 3.40$

.4 Reconnaissance resistivity study by Phoenix Geophysics, Inc. $\quad 4.85$

$\begin{array}{ll}\text {.5 Gravity interpretations } & 4.00\end{array}$

$\begin{array}{ll}.6 \text { Geochemical surveys } & 0.35\end{array}$

UT/CFS/UOC-2 Union 0il well FORMINCO \#1: Technical report including well summary, well and mud histories, $\mathrm{H}_{2} \mathrm{~S}$ kick, and geology

UT/CFS/UOC-3 Union 0il well 42-7:

.1 Technical report including we 11 summary and history, fluid history, bit record

.2 Initial flow test results

UT/CFS/UOC-4 We11 42-7: Dia-Log caliper \& Schlumberger directional surveys

UT/CFS/UOC-5 Union 0il report: "Treatment of Sanded D01omite" \& patent description of "Consolidation of Caving"

UT/CFS/UOC-6 Union 0i1 well 31-33: Technical report including well summary and history, geology, temperature-pressure survey

UT/CFS/UOC-7 Union 0 il well 31-33: Geothermal/geologic data log \& summary. of Schlumberger directional survey

UT/CFS/UOC-8 Union 0il well 14-29: Technical report with well summary \& history, geologic report. temperature-pressure survey

UT/CFS/UOC-9 Well 14-29: Schlumberger directional survey summary

UT/CFS/UOC-10 Union 0il Final Report: "Geothermal Reservoir Assessment, Cove Fort/Sulphurdale Unit, Utah" 
UT/RHS/DRI-1 Utah State well 14-2: Denver Research Inst. preliminary reservoir flow results report

UT/RHS/DRI-2 Well 14-2: Final Report of DRI flow test

UT/RHS/ESL-1

Quarterly, yearly \& cumulative epicenter maps for earthquakes:
$38.250-38.750^{\circ}$ north 1 at., 112.250 - $113.000^{0}$ west long.

(Roosevelt to Cove Fort-Sulphurdale area). 239 earthquakes for Jan 1, 1977 - Dec. 31, 1978; hypocenter parameter listing.

UT/RHS/ESL-2 Extended Self Potential Survey: Roosevelt H.S. by W.R. Sill

UT/RHS/GOC-1

Getty $0 i 1$ Co. Surface geophysical surveys, Roosevelt Hot Springs:

. 115 miles electrical resistivity survey profiles \& report by Geonomics Inc. (June 1976); 2 contoured maps with U. of Utah data 3.50 $.215 .75 \mathrm{sq}$ mi ground motion survey by Seismic Exploration Inc. (Jan 1977); computer analysis of the 5 stations

UT/RHS/GOC-2

Getty wel1 52-21: well history, bit record, lithologic log, temperature \& pressure logs

UT/RHS/GOC-3

Getty well 52-21: water analysis for 52-21 \& Jefferson well; rework history

UT/RHS/GPC-1 Geothermal Power Corp.: Shallow themal gradient hole data for 14 holes: temperature, lithology \& heat flow calculations

UT/RHS/GPC-2

"Geothermal Potential of Lands Leased by Geothermal Power Corp. in the Mineral Mountains, Beaver \& Millard Cos." by Geothermex

UT/RHS/GPC-3

Geothermal Power Corp hole \#15: lithologic log, temperature survey, water samples \& analysis, wireline sample

UT/RHS/SEI-1

Seismic Exploration Inc.: Seismic emissions study

UT/RHS/TPC-1 Thermal Power Co. well \#14-2: General well specifications, borehole data, production \& reservoir data

UT/RHS/TPC-2 Thermal Power Co. well \#72-16: General well specifications, borehole data, production \& reservoir data.

UT/ED/GG-1

Principal facts for gravity stations: Escalante Desert \& vicinity, Iron \& Washington Cos., Utah; by Win Pe \& K.L. Cook. 
OFR \#

NV/BAL/EPP-1 Geothermex report: "Geothermal Interpretation of Groundwaters, Continental Lake Region, Humboldt Co., Nevada" (Dec 1977)

NV/BAL/EPP-2 Geothermex report: "Photogeologic Interpretation of the BaltazorMcGee Geothermal Prospect, Humboldt Co., Nevada"

NV/BAL/EPP-3 Senturion Science Inc. report:" NW Nevada Microearthquake Survey Report for Earth Power Production Corp"; two, 6-station, 9-km diameter seismometer arrays

NV/BAL/EPP-4 27 shallow thermal gradient holes: temperatures, 1ithology, temperature gradient map

NV/BAL/EPP-5 Aeromagnetic map, Vya sheet: 1,015 sq mi; scale 1:62,500, flown at $9000 \mathrm{ft}$ by Scintrex Mineral Surveys in 1972

NV/BAL/EPP-6 Gravity map from USGS Open-File 76-601 \& 77-67C; o 400 sq mi

NV/BAL/EPP-7 Earth Power Production Co: Geochemical map, geologic cross section, sulfate map, microearthquake survey map

NV/BAL/EPP-8 Three deep thermal gradient holes (to $1500 \mathrm{ft}$ ): temperature logs, drilling \& completion histories, location map

NV/BAL/EPP-9. Dipole-dipole resistivity survey, 10 line miles at a=1500 ft; self-potential survey, 20 line miles at 200 meter stations; by Mining Geophysical Surveys Inc. (Mar 1980)

NV/BAL/EPP-10 Geochemical soil survey (Hg, As) for 173 samples at $1000 \mathrm{ft}$ station spacing covering o 5 sq mi 
BEOWAWE AREA, LANDER AND EUREKA COS., NEVADA

OFR \#

$\underline{\operatorname{cosT}}$

NV/BEO/CRC-1 Dipole-dipole resistivity survey: McPhar Geophysics, 1974, 6 lines, $a=2000 \mathrm{ft}$.

NV/BEO/CRC-2 Dipole-dipole resistivity survey: Phoenix Geophysics Inc, 1976, $a=2000 \mathrm{ft}$

NV/BEO/CRC-3 Magnetotelluric survey: Geotronics Corp, 1976, 30 sq mi

NV/BEO/CRC-4 Self-potential survey: Terraphysics, $1977,10 \mathrm{sq} \mathrm{mi}$

NV/BEO/CRC-5

Aeromagnetic survey: Senturion Sciences, 1976, 30 sq mi, 80 line mi single level and 14 line mi multilevel

NV/BEO/CRC-6 Seismic emissions survey: Seismic Exploration Inc, 1977, 5 stations of 5 geophone arrays; 16 sq mi

NV/BE0/CRC-7 Reflection sejsmic survey: Chas B Reynolds Assoc, 1975: 17.5 1ine $\mathrm{mi}, 300$ 1b drop $3.5 \mathrm{ft}$ or $700 \mathrm{lb}$ drop $6.5 \mathrm{ft}$

NV/BEO/CRC-8 Ground noise survey with contoured ground noise power map:

Chas B Reynolds Assoc, 1974

NV/BEO/CRC-9 Ground noise survey: Senturion Sciences Inc, 1974

24.75

NV/BEO/CRC-10

GINN \#1-13 ( $\left.t d=9551^{\prime}\right)$ : well sumary \& history, pressure survey, core desc. at $9551^{\prime}$, drill stem test, water samples \& chem, formation testing service report

NV/BEO/CRC-11

ROSSI \# 21-19 ( $\left.t d=5680^{\circ}\right)$ : dril1 \& completion report, directional survey, static temp \& press surveys, flow test, fluid chemistry, cuttings description

NV/BEO/CRC-12 Reflection Seismic survey: 3 lines totalling 8 line mi COP coverage, 3-5 1b charge at $35 \mathrm{~m}$ depth; 2 ms sample interval; 5 stacked profiles plus line location map

NV/BEO/CRC-13

Self-potential survey: $300-500 \mathrm{ft}$ stations, $4 \mathrm{sq}$ mi, map 1:1000

NV/BEO/CRC-14

Chevron well 85-18: daily drilling report, Baroid mud report

8.00

NV/BEO/CRC-15

Chevron shallow temp. gradient holes: lithologic desc., temp. data

12.50

NV/BEO/CRC -16

Beowawe Geothermal Area Evaluation Final Report, by J: Iovenitti

NV/BEO/GOC-1

Electrodyne Surveys Inc report: gravity \& magnetic survey; MT-AMT \& gaivanic resistivity; TDEM; interpretative report; maps; sections

$\mathrm{NV} / \mathrm{BEO} / \mathrm{GOC}-2$

Geophysical surveys part B: Appendices II, III, IV with data from galvanic \& magnetotelluric soundings, gravityidata

NV/BEO/GOC-3

Getty 0il Co: well histories of $14 \frac{1}{2}$ temperature gradient holes:

2 temp runs/hole 30 days apart \& 1 month after drilling

NV/BEO/GOC-4 Drilling summary, blowdown test summary \& chemical analysis for Collins well 76-17 
COLADO HOT SPRINGS, PERSHING CO., NEVADA

OFR \#

$\underline{\cos T}$

NV/COL/GOC-1 Getty 0 il Co.: "An Electrical Resistivity Survey of Colado H.S., vol. I \& II" by Electrodyne Surveys Inc.; resistivity, grav \& magnetic recon surveys, scalar \& vector AMT-MT, roving vector telluric soundings, d.c. resis \& time domain elec \& mag field soundings; 14 maps, about 100 sq mi coverage

NV/COL/GOC-2 Getty 0 il wells RG-1 \& RG-2: temperature gradient survey, 1976, $\left(t d=450^{\prime} \& 445^{\prime}\right)$

NV/COL/GOC-3 Getty 0 il temperature data for 18 temp grad holes ( $\left.t d=500^{\prime}\right)$

\section{DESERT PEAK, CHURCHILL CO., NEVADA}

OFR \#

NV/DP/PPC-1 Phillips Petroleum: geologic map, 2 cross sections, magnetotelluric slice map

NV/DP/PPC-2 Ground magnetics map \& gravity map, Carson Sink area

NV/DP/PPC-5

Phillips Petroleum Co.: "Final Report for Geothermal Reservoir Assessment Case Study"; integrated summary of drilling history \& results for DP \#B-23-1 and Humboldt House wel1 Campbe11 E-\#2

\section{DIXIE VALLEY, CHURCHILL CO., NEVADA}

OFR Al:

NV/DV/SR-1

NV/DV/SR-2

Southland Royalty 6 temp grad holes 1ithology data ( $t d=500-1500^{\prime}$ )

$\underline{\cos T}$

3.60

$N V / O V / S R-3$

Geothermex report: "Geothermal Potential of the Quest Leasehold, Qixie Valley, Nevada" 1976

"Preliminary Evaluation of Dixie Valley Geothermal Potential and Associated Economics" by Kepplinger \& Assoc, 1977 
NV/OV/SR-5 "Seismicity Report of the Dixie Valley Prospect" by Micro-

NV/DV/SR-6

NV/DV/SR-7

NV/DV/SR-8

NV/DV/SR-9

NV/DV/SR-10

NV/DV/SR-11

NV/DV/SR-12

NV/DV/SR-13

NV/DV-SR-14

NV/DV/SR-15

NV/DV/SR-16

NV/DV/SR-17 geophysics Co., 1976; 200 sq mi

"High Precision Multilevel Aeromagnetic Survey over Dixie Valley Part I" by Senturion Sciences, $1977 ; 100 \mathrm{sq} \mathrm{mi,} 5$ profiles

"High Precision Multilevel Aeromagnetic Survey Part II" by Senturion Sciences, $1978 ; 50 \mathrm{sq} \mathrm{mi,7}$ profiles

"South Dixie Valley, Nevada Scalar Magnetotelluric Survey" by Senturion Sciences, 1978; 20 sq mi, 27 scalar stations

"Interim Evaluation of Exploration \& Development Status, Geothermal Potential \& Associated Economics, Dixie Valley" by Kepplinger

Temperature survey data, 6 thermal gradient holes ( $t d=500-1500^{\prime}$ )

Dixie Federal well \#45-14 ( $\left.t d=9022^{\prime}\right)$ : well history, daily drilling report, temp-press \& directional surveys, chem analysis of fluid

Dixie Federal \#66-21 ( $\left.t d=9780^{\prime}\right)$ : well history, daily drilling rpt: bit record, directional survey, static temp \& press survey, 24hour flow test, circulation \& caustic wash record, rig test rpt

"Geothermal Reservoir Assessment Case Study, northern Basin \& Range Province, northern Dixie Valley - Final Report" by Mackay Minerals Research Inst.; vol. I 248 p.; vol II 8 plates

Reflection seismic survey (Vibroseis): 3 lines totaling 16 line miles; 8 stacked \& F-D migrated sections; location map; report by Haskins-Pfeiffer, Inc.

Thermal gradient holes SR-3 \& SR-4 $\left(t d=1500^{\prime}\right)$ : temperature survey, well histories, lithologic logs, thin section study, location map 4.60

Mackay School of Mines Case Study Report vol. III: Dixie Valley soil geochemistry \& petrochemical study; 170 pages, 9 plates

17.05

Mackay School of Mines, vol. III Appendix: Environmental Isotope Hydrology Study 
HUMBOLDT HOUSE, PERSHING CO., NEVADA

OFR \#

$\underline{\cos T}$

NV/HUM/PPC-1 Phillips Petroleum Co.: surface geologic map, cross section, magnetotelluric slice map

NV/HUM/PPC-2 Phillips well Campbell E\#1: lith log, daily drilling report, directional survey

(see also NV/DP/PPC-5)

0.85

\section{LEACH HOT SPRINGS, PERSHING CO., NEVADA}

OFR \#

NV/LCH/AMN-1 Water geochemistry and hydrothermal alteration study

COST

1.25

NV/LCH/AMN-2 Gravity survey data \& interpretation; 500 new gravity stations plus interpretation of 900 stations by EDCON

NV/LCH/AMN-3 Geologic report \& Kelsh Plotter Photomapping (blk \& white photos)

\section{MCCOY AREA, CHURCHILL \& LANDER COS., NEVADA}

OFR \# NV/MC/AMAX-1

NV/MC/AMAX-2

NV/MC/AMAX-3

NV/MC/AMAX-4

NV/MC/AMAX-5

NV/MC/AMAX-6

NV/MC/AMAX-7

NV/MC/AMAX-8
Thermal gradient/lithologic study of 15 holes ( $t d=38 \mathrm{~m}$ ) by AMAX. Location map, temperature profiles, computer representation of temperature data, 1ithologic description

Thermal gradient/lithologic study of 25 holes $\left(t d=300^{\prime}\right)$. Location map, temp profiles, computer rep. of temp data, lith description

Gravity survey by Microgeophysics Corp \& AMAX. 363 stations over approx. $70 \mathrm{sq}$ mi area

Self-potential survey of 9 lines, approx. 12 mi each with station spacing of $450 \mathrm{ft}$; by Microgeophysics Corp

Telluric-magnetotelluric survey by Terraphysics. Rotated sensor data from 14 5-component bases \& 26 telemetered orthogonal pair satellites over approx. 70 sq mi

Aeromagnetic study by Geometrics. Approx. 450 line miles, line spacing $1 \mathrm{mi}$, flown at $1000^{\prime}$ mean terrain clearance. Line location, contoured magnetic intensity maps

Microearthquake survey by Microgeophysics. Approx. 22 stations covering about 70 sq mi

"The McCoy Geothermal Prospect - An Interim Case History" by Arthur L. Lange (AMAX Exploration Inc) 
McCOY AREA, CHURCHILL \& LANDER COS., NEVADA

OFR \#

NV/MC/AMAX-9

NV/MC/AMAX-10

NV/MC/AMAX-11

NV/MC/AMAX-12

NV/MC/AMAX-13
Resistivity survey by Mining Geophysical Surveys Inc.

Magnetotelluric profiles by AMAX Exploration Inc

"McCoy Area 1980 Annual Report" by AMAX Exploration Inc \&

"McCoy Area 1981 Annual Report"

Lithologic description \& temperature/depth log for 25-9 \& 38-9

Composite well logs for wells $14-7$ and $66-8$
$\underline{\operatorname{cosT}}$

3.00

3.60

5.25

2.75

1.90

\section{SAN EMIDIO, WASHOE CO., NEVADA.}

OFR \#

$\underline{\cos T}$

NV/SE/CRC-1 Electrical resistivity survey by McPhar. Geophysics, 1973: 25 line miles, dipole-dipole, $a=2000^{\prime}$

NV/SE/CRC-2 Dipole-dipole resistivity survey by Phoenix Geophysics Inc., 1973, 8 ine miles, $a=2000^{\prime}$

NV/SE/CRC-3 Self-potential survey by Senturion Sciences, 1974: 126 measurements (spacing 1000') along 3 north-south lines

NV/SE/CRC-4 Gravity survey by Photogravity Inc, 1975: 1056 stations, 1/8 mile spacing, lines $\frac{1}{2}$ mile apart with tie lines \& terrain correction

NV/SE/CRC-5 Seismic/ground noise survey by Senturion Sciences, 1974: 35 stations, $100 \mathrm{sq}$ miles

NV/SE/CRC-6 Seismic reflection survey by Western Geophysical Co, 1976: 2.1 line miles, high resolution, $700 \%$ stacked sections migrated

NV/SE/CRC-7

Seismic reflection survey by United Geophysical Co, 1977: 10 line miles, split spread, $110^{\prime}$ group interval, processed, deconvolved

NV/SE/CRC-8

Temperature gradient report by Geonomics, 1976-7-8: temp \& 1ithologic data for 64 holes ( $\left.t d=200-500^{\prime}\right)$

NV/SE/CRC-9

Aerial \& structural geology by Intra-Search; $1: 24,000 ; 50$ miles $^{2}$

0.55

NV/SE/CRC- 10

KOSMOS \#1-9 (td=5370'): drilling history \& summary, directional survey, fluid analysis, lithologic $10 \mathrm{~g}$, core description, drill stem test, Johnston-Schlumberger technical report

NV/SE/CRC-11

KOSMOS \#1-8 (td=4013'): drilling history, lithology, drill stem test, sidewall sample desc., max-reading thermometer survey, Johnston-Schiumberger technical report 
SODA LAKE, CHURCHILL CO., NEVADA

$\underline{\text { OFR 非 }}$

$\underline{\operatorname{cosT}}$

NV/SL/CRC-1 Dipole-dipole resistivity survey by McPhar Geophysics, 1973-4:

63 sq miles, $a=2000^{\prime}, n=1-4$

NV/SL/CRC-2 Magnetotelluric survey by Geotronics, 1975: 14 stations, $20 \mathrm{Mi}^{2} 6.05$

NV/SL/CRC-3 Magnetotelluric survey by Geotronics, $1977 \quad 8.80$

NV/SL/CRC-4 Reflection sesimic survey by Reynolds \& Assoc;: 1975, 24 1ine mi. 5.50

NV/SL/CRC-5 Reflection sejsmic survey by Chevron Geophysical Co, 1977: 1200\% stacked CDP sections \& base map, 12 line mi

NV/SL/CRC-6 Temperature gradient survey \& cuttings desc., by Boyles Bros, 1974: eleven $500^{\prime}$ holes

NV/SL/CRC-7 Temp gradient hole \#36-78 (td=2000'): drill history \& lithology 0.40

NV/SL/CRC-8 Well \#44-5 ( $\left.t d=5070^{\prime}\right)$ : drilling \& completion history, directional survey, core \& lithologic descriptions

NV/SL/CRC-9 Well \#1-29: drilling \& completion history, flow test data, production record, static temp mud $10 \mathrm{~g}$, report of analysis

NV/SL/CRC-10 Chevron Resources Co. Final Report: "Geothermal Reservoir Assessment, Intermediate Depth holes $11-33$ and $63-33^{\prime \prime}$

\section{STILLWATER, CHURCEILL CO., NEVADA}

OFR 非

$\operatorname{cosT}$

NV/STR/UOC-1 GSI reflection seismic survey (Vibroseis source): 3 lines totaling 12 line mi, location map, velocity analysis, final CDP stack

NV/STR/UOC-2 Union 0il Co Technical report on well De Braga \#2: includes well sumary, geologic report, fluid analysis

NV/STR/UOC-3 Addendum to report on De Braga \#2: flow test \& fluid sample

NV/STR/UOC-4 Technical report on well Richard Weishaupt \#1; "1981 Final Report on Stillwater Prospect" by Union 011 Co 
TUSCARORA, ELKO CO., NEVADA

OFR \#

$\underline{\operatorname{cosT}}$

NV/TUS/AMAX-1 Thermal gradient/lithology study of 4 holes ( $t d=50-60 \mathrm{~m}$ ): location map, temp profiles, lithologic desc, computerized temp data

NV/TUS/AMAX-2 Thermal gradient/lithology study of 33 holes ( $t d=150-250 \mathrm{ft}$ ) : and 6 holes ( $t d=1000-1750 \mathrm{ft}$ ): location map, temp profiles, lithologic desc, thermal studies contour maps, computerized temp data

NV/TUS/AMAX-3 Gravity survey by Microgeophysics Corp: 314 stations, 200 sq mi. 3.00

NV/TUS/AMAX-4 Self-potential survey, Microgeophysics Corp: 9 lines of 12 mi each, station spacing $200 \mathrm{~m}$, with 100-50 $\mathrm{m}$ fill-in

NV/TUS/AMAX-5 Magnetotelluric survey by Terraphysics: 30 stations, with 11 fivecomponent bases \& 19 telemetered orthogonal pairs; $70 \mathrm{sq} \mathrm{mi}$

NV/TUS/AMAX-6 Aeromagnetic survey by Geometrics: approx 375 1ine miles, spacing of $1 \mathrm{mi}$ flown at $1000 \mathrm{ft}$; location map, contoured mag intensity

NV/TUS/AMAX-7 Microearthquake survey by Microgeophysics Corp: approx 30 stations \& $70 \mathrm{sq} \mathrm{mi}$, P-wave delay study.

NV/TUS/AMAX-8

Dipole-dipole resistivity study by Mining Geophysics: 3 1 ines of 2000-ft dipoles totaling 34 Tine miles

NV/TUS/AMAX-9 Magnetotelluric survey by Terraphysics -supplements NV/TUS/AMAX-5

NV/TUS/AMAX-10

Wel1 \#66-5 (td=5456 ft): drilling summary, geothermal log, gradient plot, lithologic log, flow test (by Enthalpy), directional survey 2.20

NV/TUS/AMAX-11 Geochemical soil survey for 17 elements; maps: $\mathrm{NH}_{3}, \mathrm{Li}, \mathrm{F}, \mathrm{B}, \mathrm{Hg}$, $\mathrm{Sb}, \mathrm{As}, \mathrm{Bi}, \mathrm{Cl}, \mathrm{Mn}, \mathrm{Ag}, \mathrm{Ni}, \mathrm{Pb}, \mathrm{Fe}, \mathrm{Cu}, \mathrm{Mo}, \mathrm{Zn}$

NV/TUS/AMAX-12 "The Tuscarora Geothermal Prospect - A Continuous Case History" by F.E. Berkman, AMAX Exploration Inc

NV/TUS/AMAX-13 Tuscarora soil geochemistry

NV/TUS/AMAX-14 Tuscarora magnetotelluric profiles

NV/TUS/AMAX-15 Final Report - Tuscarora Area by H.D. Pilkington, AMAX Explor. 


\section{PART IV}

CATALOG OF THE GEOTHERMAL SAMPLE LIBRARY TO DATE - OCTOBER 1982 


\section{LOCATION MAP DRILL HOLE SAMPLES}

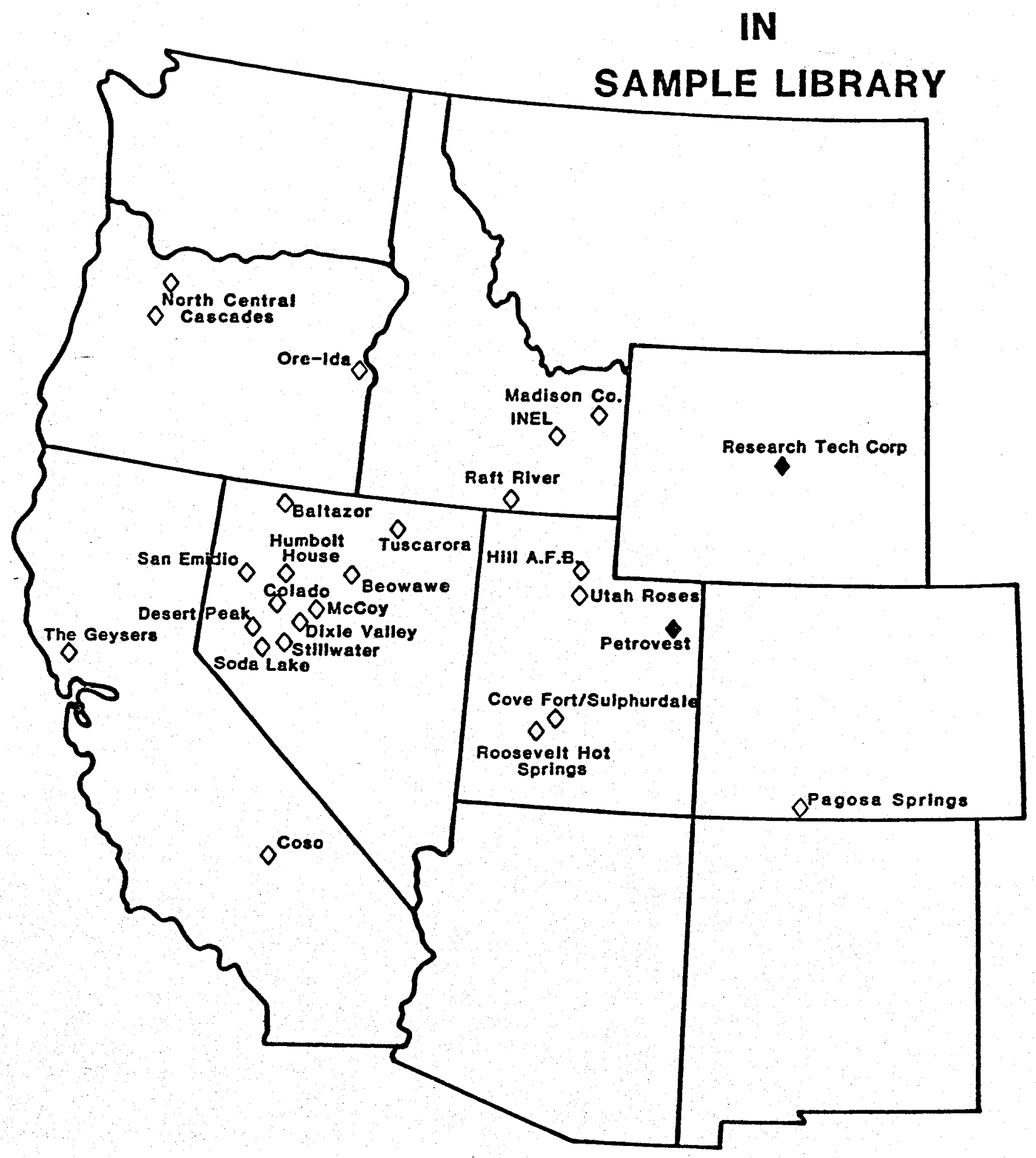


CAL IFORNIA

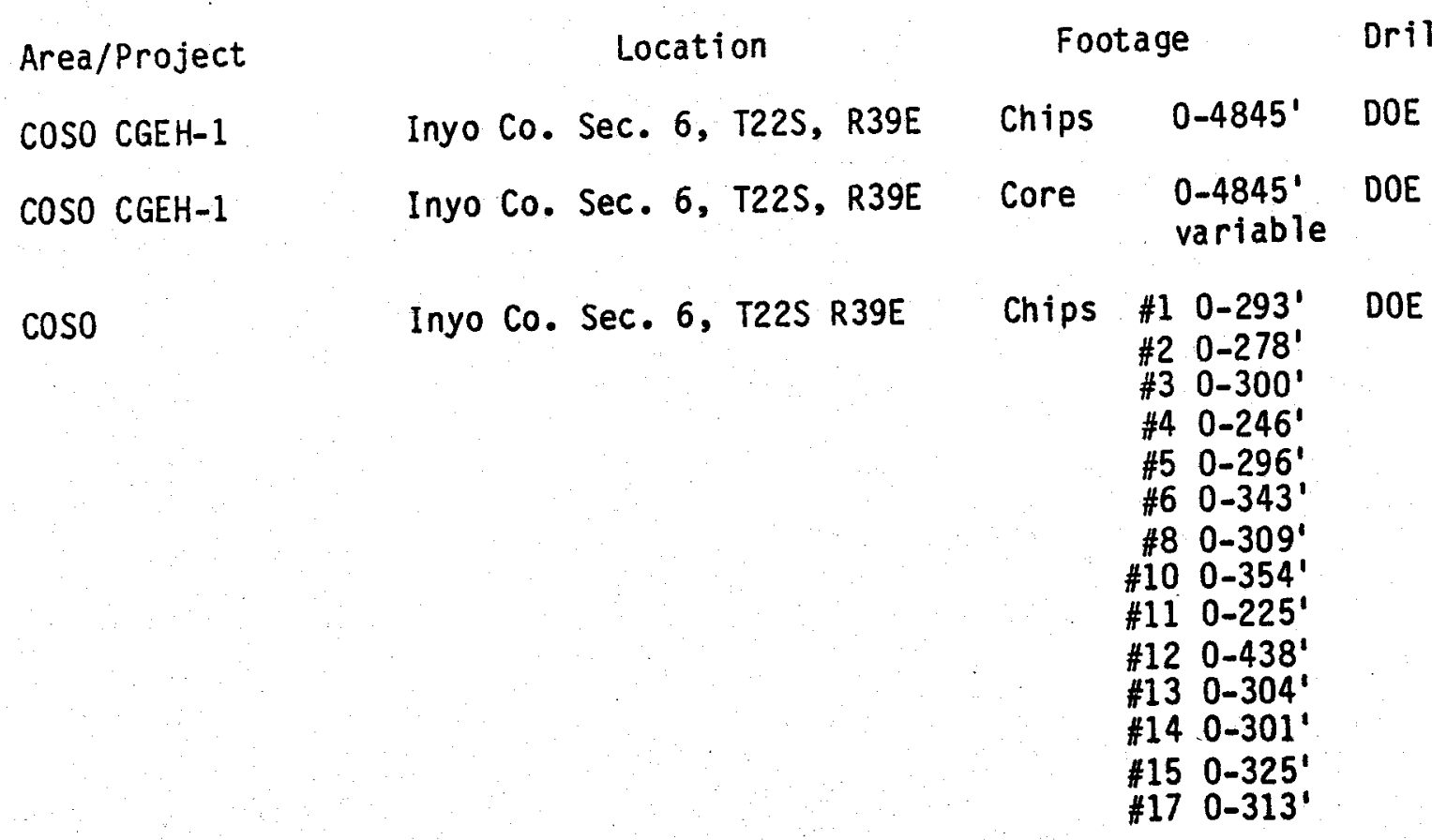

COSO BDSH-1 Inyo Co. Sec. 6, T22S R39E Core 11'-1342' DOE

\section{COLORADO}

Area/Project

Pagosa Springs PS -3

Pagosa Springs PS-4

Pagosa Springs PS-5
Location

Archuleta Co.

Archuleta Co.

Archul eta Co.
Footage

Chips

Chips

Chips $0-240^{\prime}$

$0-300^{\prime}$

$0-200^{\prime}$
Driller

Chaffee Geothermal

Chaffee Geothermal

Chaffee Geothermal 
IDAHO

Area/Project

MCG \#1

INEL

INEL

Raft River RRGE\#1

Raft River RRGE\#2

Raft River RRGE\#3

Raft River RRGE\#3C

Raft River RRGP\#4

(Leg B)

Raft River RRGP\#5

Raft River RRGI\#6

Raft River RRGI\#7
Location

Madison Co. Sec. 31 T6N R40E

Butte Co. Sec. 1 T3N R29E

Butte Co. Sec. 1 T3N R29E

Cassia Co. Sec. 23 T15S R26E

Sec. 23 T15S R26E

"

u

u

11

a

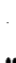

Sec. 25 TI5S R26E Core Variable DOE

Footage

Driller

Chips 200-3140' Energy Service Inc.

Chips $0-10,324^{\prime} \quad$ DOE

Core Variable DOE

Core Variable DOE

Core Variable DOE

Core Variable DOE

Sec. 22 TI5S R26E Core Variable DOE

Sec. 25 T15S R26E Core Variable DOE

Sec. 25 T16S R26E Core Variable DOE 
NEVADA

Area/Project

Beowawe B-2-79

Beowawe B-7-79

Beowawe B-9-79

Beowawe B-11-79

Beowawe B-14-79

Beowawe B-19-79

Beowawe B-20-79

Beowawe $8-22-79$

Beowawe B-24-79

Beowawe B-25-79

Beowawe B-27-79

Beowawe B-29-79

Beowawe B-31-79

Beowawe B-32-79

Beowawe B-33-79

Beowawe B-35-79

Beowawe B-37-79

Beowawe B-38-79

Beowawe B-39-79

Beowawe $8-46-79$

Beowawe B-47-79

Beowawe B-48-79

Beowawe 8-49-79

Beowawe B-50-79

Beowawe $B-51-79$
Location

Eureka Co. Sec. 5 T31N, R48E

Lander Co. Sec. 18 T3IN R48E

Eureka Co. Sec. 9 T31N R48E

Lander Co. Sec. 18 T31N R48E

Lander Co. Sec. 13 T31N R47E

Lander Co. Sec. 18 T31N R48E

Lander Co. Sec. 18 T31N R48E

Lander Co. Sec. 18 T31N R48E

Lander Co. Sec. 18 T3IN R48E

Lander Co. Sec. 18 T3IN R48E

Lander Co. SeC. 18 T31N R48E

Eureka Co. Sec. 13 T31N R47E

Lander Co. Sec. 18 T31N R48E

Lander Co. Sec. 18 T31N R48E

Eureka Co. Sec. 12 T3IN R48E

Eureka Co. Sec. 16 T31n R48E

Lander Co. Sec. 18 T31N R48E

Lander co. Sec. 18 T31N R48E

Eureka Co. Sec. 17 T3IN R48E

Eureka Co. Sec. 13 T3IN R48E

Eureka Co. Sec. 20 T3IN R48E

Eureka Co. Sec. 21 T3IN R48E

Eureka Co. Sec. 24 T3IN R48E

Lander Co. Sec. 18 T3IN R48E

Lander Co. Sec. 19 T31N R48E
Chips

Chips

Chips

Footage

Driller

Chips 0-500 Chevron

Chips $0-500^{\prime}$ Chevron

Chips 0-500' Chevron

Chips 0-500 Chevron

Chips $0-500^{\prime}$ Chevron

Chips 0-500' Chevron

Chips $0-340^{\prime}$ Chevron

Chips 0-500 Chevron

Chips $0-450^{\prime}$ Chevron

Chips. $0-430$ 'Chevron

Chips $0-240^{\prime}$ Cherron

Chips 0-460' Chevron

Chips $\quad 0-450^{\prime}$ Chevron

Chips 0-500' Cherron

Chips $0-200^{\prime}$ Chevron

Chips $0-500^{\prime}$ Chevron

Chips 0-290' Chevron

Chips 0-500' Chevron

Chips 0-420 Chevron

Chips $\quad 0-390^{\circ}$ Cherron

Chips $0-490^{\prime}$ Chevron

0-500' Chevron

$0-330^{\prime}$ Chevron

Chips 0-430 Chevron 
NEVADA (cont.)

Area/Project

Beowawe B-51-79

Beowawe B-54-79

Desert Peak $B$

No. 23-1

Humboldt House

Campbell "E" \#2

Colado 8-34

Colado 1-12

Colado 9-34

Colado 3-10

Colado 4-16

Colado 12-26

Colado 2-2

Colado 15-21

Colado 10-34

Colado 6-6

Colado 16-22

Colado 5-8

Colado 17-24

Colado 7-4

Colado 18-24

Colado 13-26

Colado 14-22

Colado 11-36

Dixie Federal 45-14 Churchill Co. Sec. 14 T23N R35E Chips

Colado $1 \mathrm{GH}-1$

Location

Lander Co. Sec. 19 T31N R48E Chips

Churchill Co. Sec. 23 T22N R27E Chips

Pershing Co. Sec. 15 T31N R33E Chips

Pershing Co. Sec. 34 T28N R32E Chips

Pershing Co. Sec. 12 T27N R32E Chips

Pershing Co. Sec. 34 T28N R32E Chips

Pershing Co. Sec. 10 T27N R32E Chips

Pershing Co. SeC. 16 T27N R32E Chips
Footage

$0-140^{\prime}$

$0-450^{\prime}$

$0-9615^{\prime}$

$0-8061$

$0-500^{\prime}$

$0-500^{\prime}$

$0-500^{\prime}$

$0-500^{\prime}$

$0-500^{\prime}$

$0-300^{\prime}$

$0-500^{\prime}$

$0-500^{\prime}$

$0-500^{\prime}$

$0-500$ !

$0-500^{\prime}$

$0-500^{\prime}$

$0-500^{\prime}$

$0-500^{\prime}$

$0-500^{\prime}$

$0-500^{\prime}$

$0-500^{\prime}$

$0-500^{\prime}$

$0-9020$

$0-1500^{\prime}$
Getty $0 \mathrm{il}$

Getty 0 il

Getty 0 il

Driller

Chevron

Chevron

Phillips

Phillips

Getty 0 il

Getty 0 il

Getty 011

Getty 011

Getty 0 il

Getty $0 \mathrm{il}$

Getty $0 \mathrm{il}$

Getty $0 i 1$

Getty 0 il

Getty 011

Getty 0 il

Getty 011

Getty 0 il

Getty $0 i 1$

Getty 011

Thermal Power

Getty 0 il 
NEVADA (cont.)

Area/Project

Colado $1 \mathrm{GH}-2$

Dixie Federa

McGee \#2

Baltazor 1500-1

Balt azor 1500-7

McGee \#155

McGee \#145

Baltazor 143-A

Baltazor \#2

McGee 150

Baltazor 215

Baltazor 101-99

Balt azor/Howard \#189

Baltazor 117

Baltazor 213

Baltazor 101-12

Baltazor 101-5

MCGee 101-9

Baltazor 101-7

Baltazor 101-6

Soda Lake 44-5

Soda Lake 1-29

Beowawe Ginn 1-13

Beowawe Rossi 21-9
Location

Footage

Persinghin Co. SeC. 10 T27N R32E Chips

$0-1160^{\prime}$

$0-9780^{\prime}$

$0-1680^{\prime}$

Humboldt Co. Sec. 26 T45N R27E Chips

Humbol dt Co. Sec. 13 T46N R28E Chips

$0-1581^{\prime}$

Humboldt Co. SeC. 14 T46N R28E Chips

$0-1487$

Humboldt Co. Sec. 29 T45N R27E Chips

$0-280^{\circ}$

Humboldt Co. Sec. 1 T45N R27E Chips

$0-240^{\prime}$

Humboldt Co. Sec. 10 T45N R27E Chips

Humboldt Co. Sec. 3 T46N R28E Chips

Humboldt Co. Sec. 27 T45N R27E Chips

Humboldt Co. Sec. 14 T46N R28E Chips

Humboldt Co. Sec. 16 T47N R3OE Chips

Humbolat Co. Sec. 24 T44N R31E Chips

Humboldt Co. Sec. 16 T46N R28E Chips

Humbol dt Co. Sec. 1 T46N R28E Chips

Humboldt Co. Sec. 5 T47N R3OE Chips

Humboldt Co. Sec. 7 T47N R3OE Chips

Humboldt Co. Sec, 2 T44N R27E Chips

Humboldt Co. Sec. 34 T46N R28E Chips

Humboldt Co. Sec. 36 T42N R29E Chips

Churchill Co. Sec. 5 T29N R28E Chips

Churchill Co. Sec. 29 T2ON R28E Chips

Lander Co. Sec. 13 T3IN R47E Chips

Lander Co. Sec. 19 T31N R48E Chips $0-200^{\circ}$

$0-170^{4}$

$0-290^{\circ}$

$0-100^{\prime}$

$0-300^{\prime}$

$0-200^{\prime}$

$0-220^{\prime}$

$0-260^{\prime}$

$0-270^{\prime}$

$0-100$ !

$0-300^{\prime}$

$0-300$

$0-280^{\prime}$

0.50691

$0-4306^{\prime}$

$0-6350^{\prime}$

$0-5686^{\prime}$
Driller

Getty 0 il

Thermal Power

Earth Power Pro. Co.

Earth Power Pro. Co.

Earth Power Pro. Co.

Earth Power Pro. Co.

Earth Power Pro. Co.

Earth Power Pro. Co.

Earth Power Pro. Co.

Earth Power Pro. Co.

Earth Power Pro. Co.

Earth Power Pro. Co.

Earth Power Pro. Co.

Earth Power Pro. Co.

Earth Power Pro. Co.

Earth Power Pro. Co.

Earth Power Pro. Co.

Earth Power Pro. Co.

Earth Power Pro. Co.

Earth Power Pro. Co.

Chevron Resources

Chevron Resources

Chevron Resources

Chevron Resources 
Nevada (cont.)

Area/Project

San Emidio Kosmos 1-9

DeBraga \#2

Soda Lake 11-33

Soda Lake $63-33$

Dixie Valley SR-4

Tuscarora 860-33

Tuscarora $860-41$

Tuscarora $860-42$

San Emidio Kosmos 1-8

Beowawe USL-GBP \#2 Lander Co. Sec. 17 T31N R48E

Beowawe USL-GBP \#5 Lander Co. Sec. 16 T31M R4BE

Beowawe USL-GBP \#6 Lander Co. Sec. 20 T3IN R48E

Beowawe USL-GBP \#7 Lander Co. Sec. 22 T3IN R48E

Beowawe USL-GBP \#9 Lander Co. Sec. 22 T31N R48E

Beowawe USL-GBP \#15 Lander Co. Sec. 20 T31N R48E

Beowawe USL-GBP \#17 Lander Co. Sec. 16 T31N R48E

Baltazor 122

Humboldt Co. Sec. 25 T46N R28E Chips

Beowawe GBP \#10

Eureka Co. Sec. 22 T3IN R48E

Beowawe GBP \#12

Eureka Co. Sec. 14 T31N R48E Chips

Beowawe GBP \#13

Eureka Co. SeC. 14 T31N R48E Chips

Beowawe GBP \#14

Eureka Co. Sec. 11 T31N R48E

Eureka Co. Sec. 20 T31n R48E

Beowawe GBP \#16

Beowawe unit 85-18
Footage

Chips $0-5356^{\prime}$

$0-6700^{\prime}$

$0-2000^{\prime}$

$0-2000^{\prime}$

$0-1500^{\prime}$

$0-770^{\circ}$

$0-1000^{\prime}$

$0-1740^{\prime}$

$0-4013^{\prime}$

$0-500^{\prime}$

$0-500^{\prime}$

$0-500^{\prime}$

Chips

$0-500^{\prime}$

$0-500$

$0-480^{\prime}$

$0-500^{\prime}$

$0-5001$

$0-280^{\prime}$

$0-500^{\prime}$

$0-440^{\prime}$

$0-460^{\prime}$

Chips

$0-300^{\prime}$

Chips

$0-440^{\prime}$
Chips $0-5400^{\prime}$ Getty 0 il

Driller

Chevron Resources

Union 0 il

Chevron Resources

Chevron Resources

Southland Royalty Co.

AMAX

AMAX

AMAX

Chevron Resources

Getty 011

Getty 011

Getty 011

Getty 011

Getty 0il

Getty 0 il

Getty Dil

Getty $0 i 1$

Earth Power Pro. Co.

Getty $0 i 1$

Getty 011

Getty 011

Getty 0 il

Getty 011 
NEVADA (cont.)

Area/Project Location footage Driller

SUNEDCO 11-36 Leach Hot Spring, Pershing Co. Chips 0-8565' AMINOIL

McCoy 66-8 Churchill Co. Chips 0-2500' AMAX

MeCoy 14-7 Churchill Co. Chips 0-940 AMAX

McCoy 864 Chruchill/Lander Co. sent all chips to AMAX AMAX

Dixie Valley SR-3 Churchill Co. SeC. 32 T25N R37E Chips 0-1500' Southland Royalty Co.

USL $44 X-10 \quad$ Pershing Co. Sec. 10 T27N R32E Chips 1215-7950' Getty 011

AMAX 52-9 Elko Co. Sec. 5 T41N R52E Chips 0-3120 AMAX

Tuscarora 860-32 Elko Co. Sec.6 T41N R52E Chips 0-1020' AMAX

Tuscarora 860-34 Elko Co. Sec. 14 T41N R52E Chips 0-1040' AMAX

Tuscarora 860-36 Elko Co. Sec. 29 T42N R52E Chips 0-300' AMAX

Tuscarora 860-43 Elko Co. Sec. 35 T41n R52E Chips 0-1040' AMAX

Tuscarora 66-5 El ko Co. Sec. 5 T41N R52E Chips 0-4350' AMAX

Beowawe Collins Eureka Co. Sec. 17 TI3N R48E Chips 1200-9000 Getty 017 76-17 
OREGON

Area/Project

Location

Footage

Driller

No. Central Cascade \#1 Linn Co. Sec. 32 T13S R7E Chips 0-1837' Southland Royalty Co.

No. Central Cascade \#2 Linn Co. Sec. 9 T12S R7E Chips 0-1965' Southland Royalty Co.

No. Central Cascade \#3 Clackamas Co. Sec. 5 T7S R8E Chips 0-960' Southland Royalty Co.

No. Central Cascade \#4 Clackamas Co. Sec. 10 T7S R8E Chips 0-1160' Southland Royalty Co.

No. Central Cascade \#5 Clackamas Co. Sec. 6 T8S R8E Chips 0-730' Southland Royalty Co.

No. Central Cascade \#6 Clackamas Co. Sec. 6 T8S R8E Chips 0-1510' Southland Royalty Co.

Fenix and Scission

Clackamas Co. Sec. 15 T2S R8E Chips 0-6018' Fenix and Scission

01d Maid Flat $7 A$

Ore-Ida \#1

Malheur Co. Sec. 3 TI8S R47E Chips 0-10,054' Ore-Ida Foods

Ore-I da \#I

Malheur Co. Sec. 3 TI8S R47E Core Variable Ore-Ida Foods 
UTAH

Area/Project

Union 0i1 31-33

Union $42-7$

Formineo \#1

Getty $52-21$

Getty 52-21

TPC 72-16

GPC-1

GPC -2

GPC-3

GPC -4

GPC-5

GPC-6

GPC- 7

GPC-8

GPC-9

GPC -10

GPC-11

GPC -12

GPC-13

GPC -14

GPC- 15

GPC -18

TPC-14-2

CFSU $14-29$

Utah State 24-36
Location

Millard Co. Sec. 33 T25S R6W

Beaver Co. Sec. 7 T26S R6W

Millard Co. Sec. 29 T25S R6W

Beaver Co. Sec. 21 T27S R9W

Beaver Co. Sec. 21 T27S R9W

Beaver Co. Sec. 16 T27S R9W

Beaver Co. Sec. 1 T27S R1OW

Beaver Co. Sec. 6 T27S R9W

Beaver Co. Sec. 4 T27S R9W

Beaver Co. Sec. 33 T27S R9W

Beaver Co. Sec. 34 T27S R9W

Beaver Co. Sec. 25 T27S R1OW

Beaver Co. Sec. 13 T27S R9W

Beaver Co. Sec. 25 T26S R9W

Beaver Co. Sec. 12 T26S R8W

Beaver Co. Sec. 6 T26S R8W

Beaver Co. Sec. 17 T26S R8W

Beaver Co. Sec. T26S R7W

Beaver Co. Sec. 22 T27S R7W

Beaver Co. Sec. 18 T27S R9W

Beaver Co. Sec. 18 T27S R9W

Beaver Co. Sec. T27S R7W

Beaver Co. Sec. 2 T26S R9W

Millard Co. Sec. 29 T25S R6W

Beaver Co.
Footage

Chips

Chips

Chips

Chips

Core

Chips

Chips

Chips

Chips

Chips

Chips

Chips

Chips

Chips

Chips

Chips

Chips

Chips

Chips

Chips

Chips

Chips

Chips

Chips

Chips $0-5220^{\prime}$

$0-7730^{\prime}$ Union oil Co.

0-1051' Union of Ca.

0-7500' Getty 011 Co.

Variable Getty 0il Co.

0-1244' Thermal Power Co.

0-400' Geoth. Power Corp.

$0-300^{\prime}$ Geoth. Power Corp.

0-300' Geoth. Power Corp.

0-300' Geoth. Power Corp.

$0-180^{\prime}$ Geoth. Power Corp.

0-300' Geoth. Power Corp.

0-300 Geoth. Power Corp.

0-360 Geoth. Power Corp.

$0-290^{\prime}$ Geoth. Power Corp.

0-196' Geoth. Power Corp.

0-110' Geoth. Power Corp.

0-260' Geoth. Power Corp.

0-240 Geoth. Power Corp.

0-540' Geoth. Power Corp.

0-1870 Geoth. Power Corp.

0-90' Geoth. Power Corp.

0-6100 Thermal Power Corp.

0-2620 Union 011

0-5600' Thermal Power Corp. 
UTAH (cont.)

\begin{tabular}{|c|c|c|c|c|}
\hline Area/Project & Location & Foo & tage & Driller \\
\hline KGRA 9-1 & Beaver Co. Sec. 9 T27S R9W & Chips & $0-6883^{\prime}$ & Phillips \\
\hline Hill Air Force \#1 & Davis Co. & Chips & $0-1220^{\prime}$ & Univ. of Utah \\
\hline Hill Air Force \#2 & Davis Co. & Chips & $0-3260^{\prime}$ & Univ. of Utah \\
\hline Res. Tech. Corp. & Uintah Co. Sec. 21 T5S R23E & Chips & $140-1300^{\prime}$ & Res. Tech. Corp. \\
\hline Petrovest/Jensen \#1 & Uintah Co. Sec. 21 T5S R23E & Chips & $0-2615^{\prime}$ & Res. Tech. Corp. \\
\hline Petrodyne & Uintah Co. Sec. 21 T5S R23E & Chips & $0-1300^{\prime}$ & Res. Tech. Corp. \\
\hline Petrodyne/Jensen \#3 & Uintah Co. Sec. 21 T5S R23E & Chips & $0-2545^{\prime}$ & Res. Tech. Corp. \\
\hline Utah Roses \#2 & Salt Lake Co. & Chips & $0-4910$ & Utah Rose \\
\hline Forminco A & Millard Co. & Chips & $0-300^{\prime}$ & Union 0 il \\
\hline Forminico B & Millard Co. & Chips & $0-110^{\prime}$ & Union 011 \\
\hline Fominco C & Millard Co. & Chips & $0-300^{\prime}$ & Union 0 il \\
\hline Forminco D & Millard Co. & Chips & $0-90^{\prime}$ & Union 011 \\
\hline Forminco E & Mil lard Co. & Chips & $0-300^{\prime}$ & Union $0 i 1$ \\
\hline Forminco $F$ & Millard Co. & Chips & $150-255^{\prime}$ & Union $0 i 1$ \\
\hline Fominco $G$ & Millard Co. & Chips & $0-300^{4}$ & Union 0il \\
\hline Forminco $\mathrm{H}$ & Millard Co. & Chips & $0-300^{\prime}$ & Union $0 i 1$ \\
\hline Forminco I & Millard Co. & Chips & $0-245^{\prime}$ & Union $0 i 1$ \\
\hline Forminco $\mathrm{J}$ & Millard Co. & Chips & $0-300^{\prime}$ & Union $0 i 1$ \\
\hline Forminco $\mathrm{K}$ & Millard Co. & Chips & $0-250^{\prime}$ & Union 011 \\
\hline Forminco L & Millard Co. & Chips & $0-250^{\prime}$ & Union 011 \\
\hline Fominco $M$ & Millard Co. & Chips & $0-250^{\prime}$ & Union 011 \\
\hline Forminco $\mathrm{N}$ & Millard Co. & Chips & $0-120^{\prime}$ & Union 011 \\
\hline Forminco 0 & Millard Co. & Chips & $0-250^{\prime}$ & Union $0 i 1$ \\
\hline Forminco \#1 & Millard Co. & Chips & $0-250^{\prime}$ & Union 011 \\
\hline Forminco \#2 & Millard Co. & Chips & $0-250^{\prime}$ & Union 0i1 \\
\hline
\end{tabular}




\section{UTAH (cont.)}

\begin{tabular}{lllll} 
Area/Project & \multicolumn{1}{c}{ Location } & \multicolumn{2}{c}{ Footage } & Driller \\
Forminco \#3 & Millard Co. & Chips & $0-230^{\prime}$ & Union 0il \\
Forminco \#4 & Millard Co. & Chips & $0-250^{\prime}$ Union 0il \\
Forminco \#5 & Millard Co. & Chips & $0-180^{\prime}$ Union 0il
\end{tabular}

WYOMING

Area/Project

Location

Footage

Driller

Res. Tech. Corp. Niobrara So. Sec. 11 T40N R66W Chips 1475-7850' Res. Tech. Corp. 